Document downloaded from:

http://hdl.handle.net/10251/145402

This paper must be cited as:

Istuque, D.; Soriano Martinez, L.; Akasaki, J.; Melges, J.; Borrachero Rosado, MV.; Monzó Balbuena, JM.; Paya Bernabeu, JJ... (10-0). Effect of sewage sludge ash on mechanical and microstructural properties of geopolymers based on metakaolin. Construction and Building Materials. 203:95-103. https://doi.org/10.1016/j.conbuildmat.2019.01.093

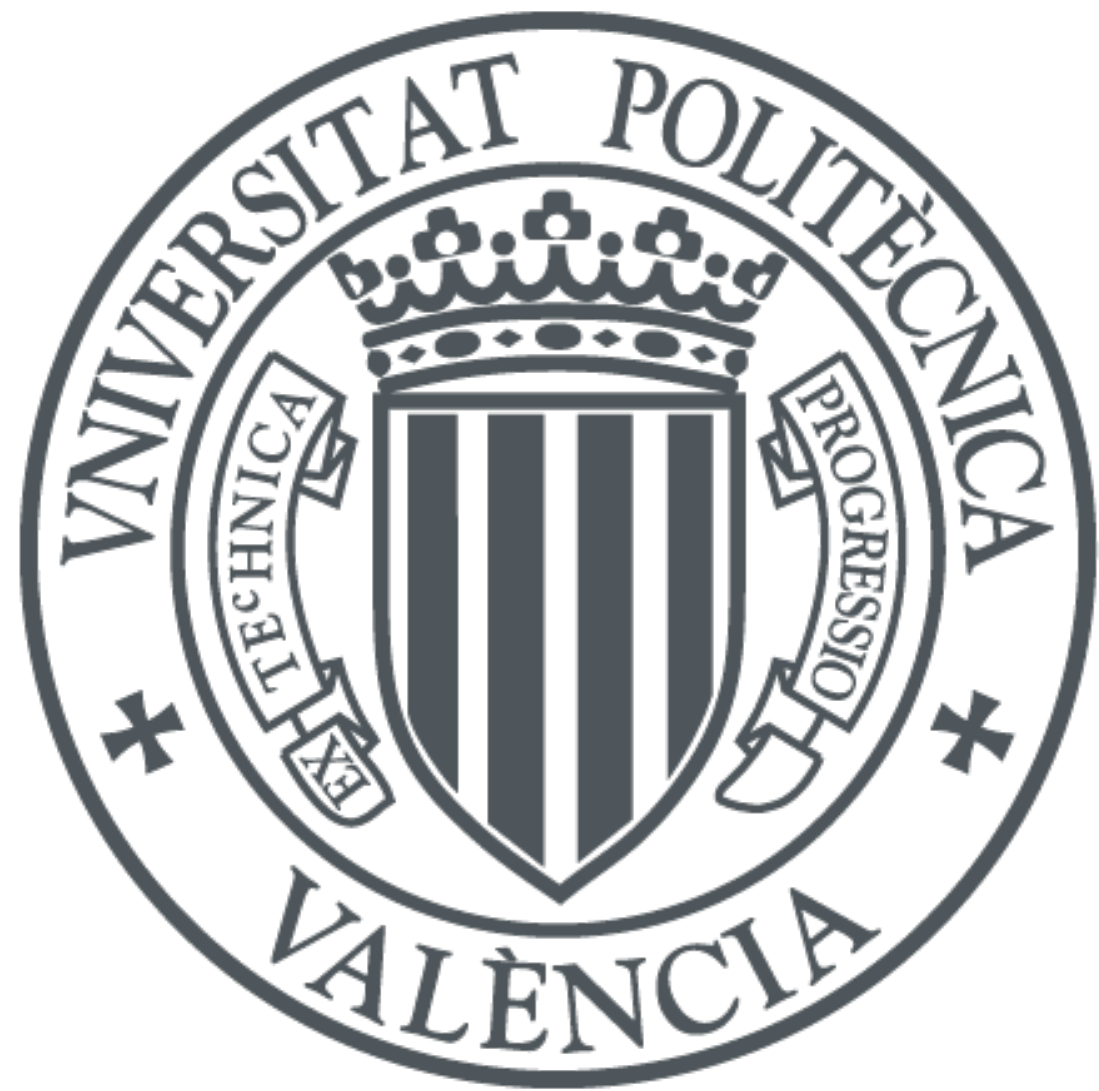

The final publication is available at

https://doi.org/10.1016/j.conbuildmat.2019.01.093

Copyright Elsevier

Additional Information 


\section{Effect of Sewage Sludge Ash on mechanical and microstructural properties of geopolymers based on metakaolin}

D.B. Istuque ${ }^{1}$, L. Soriano ${ }^{2}$, J.L. Akasaki ${ }^{1}$, J.L.P. Melges ${ }^{1}$, M.V. Borrachero ${ }^{2}$, J. Monzó ${ }^{2}$ J. Payá ${ }^{2}$, M.M. Tashima ${ }^{\star 1}$

${ }^{1}$ Universidade Estadual Paulista (UNESP), Faculdade de Engenharia de Ilha Solteira MAC - Grupo de Pesquisa em Materiais Alternativos de Construção. Ilha Solteira-SP, Brasil.

${ }^{2}$ ICITECH - Instituto de Ciencia y Tecnología del Hormigón. Universitat Politècnica de València (UPV). Valencia, España.

${ }^{*}$ Corresponding author: maumitta@hotmail.com

\section{Abstract}

This paper explored reported-the effect of sewage sludge ash (SSA) on the mechanical and microstructural properties of geopolymers based on metakaolin (MK) involving two different $\mathrm{SiO}_{2} / \mathrm{Na}_{2} \mathrm{O}$ molar ratios $\left(0.8\right.$ and 1.6), two temperature curing conditions $\left(25^{\circ} \mathrm{C}\right.$ and $\left.65^{\circ} \mathrm{C}\right)$ and various ages of curing $(1,3,7,14,28,90$ or 180 days). The geopolymers tests-were characterized performed using different techniques:-as X-ray diffraction (XRD), thermogravimetric analysis (TGA), Fourier transform infrared spectroscopy (FTIR), Scanning Electron Microscopy (SEM) and compressive strength of mortars. Tests were performed for both high $\left(65^{\circ} \mathrm{C}\right)$ and room $\left(25^{\circ} \mathrm{C}\right)$ temperature curing conditions lasting for $1,3,7,14,28,90$ or 180 days. The geopolymeric samples were activated using sodium hydroxide and sodium silicate solutions using two different $\mathrm{SiO}_{2} / \mathrm{Na}_{2} \mathrm{O}$ molar ratios (0.8 and 1.6). The compressive strength tests showed that the replacement of MK by SSA in 10 wt. $\%$ when cured at $25^{\circ} \mathrm{C}$ with the highest $\mathrm{SiO}_{2} / \mathrm{Na}_{2} \mathrm{O}$ molar ratio reaches similar compressive strengths after 14 days of curing compared to the samples with only MK, which reached a maximum compressive strength of $50.8 \mathrm{MPa}$ at 180 days. The FTIR analyses carried out in the geopolymer pastes with SSA (10 wt.\% of SSA and $90 \mathrm{wt} . \%$ of MK) showed a formation of N-A-S-H gels in the samples cured at $25^{\circ} \mathrm{C}$. The microstructural studies by XRD, TGA and SEM pointed out the formation of a crystalline phase as $\mathrm{Na}$ P-type zeolite in MK/SSA based-geopolymer pastes cured at $65{ }^{\circ} \mathrm{C}$, which explained the loss of compressive strength of the samples cured at high temperature. However, the SSA retarded the crystallization process in the MK basedgeopolymer.

Keywords: Geopolymer, Alkali-activated cement, Ash, Sewage sludge,Sewage sludge ash, Urban waste, Waste management 


\section{1. Introduction} [18-21].
Current world population is approximately 7.6 billion and the prediction for 2100 is about 11.2 billion. This represents a population increase of 53\% (United Nations, 2017). This implies exponential urban area growth and, consequently, an increase in waste generation. In this sense, environmentally friendly solutions are necessary in order to maintain the balance of nature: new approaches to waste management and a major reduction in greenhouse gas emissions.

The main contribution of the building construction sector to the reduction of these problems is mainly associated with the reuse of waste materials and the production of greener cementitious materials. In recent years, an alternative class of class of alternative-inorganic binding material, geopolymers, has drawn a lot of attention in materials science due to their mechanical properties, durability and, principally, due to the reduced environmental impact associated with their production [1-3]. Geopolymers, also called alkali-activated binders, have a tri-dimensional structure formed by a polycondensation of aluminosilicate precursors reacting with alkaline activating solution $[4,5]$. Several aluminosilicate-based materials can be used as precursors for geopolymer production, including natural (volcanic ashes, diatomaceous earth), synthetic (metakaolin) and waste materials (fly ash, blast furnace slag, ceramic, mining wastes, glasses, sludge ashes) [6-8].

Sewage sludge ash (SSA) is an ash generated from the combustion of sewage sludge from wastewater treatment plants $[9,10]$. Its production is estimated from $0.1 \mathrm{~kg}$ up to $30.8 \mathrm{~kg}$ per population equivalent per year (kg/p.e/year) in European Union [11] and the

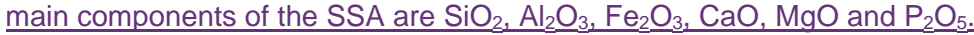

Several papers focusing on the application of SSA on Portland cement mortars, bricks, ceramics and glass production can be found on the literature [12-17]. ProblablyProbably, the main studies about SSA are related to its use as pozzolanic material in blended mortars due to the presence of amorphous $\mathrm{SiO}_{2}$ and/or $\mathrm{Al}_{2} \underline{O}_{3}$ on its chemical composition

Although SSA may exhibit a potential application as a precursor in geopolymeric systems, its use for this purpose is recent. In 2010, Yamaguchi and Ikeda [22] studied the preparation of geopolymeric materials from sewage sludge slag. At room
Con formato: Fuente: (Predeterminada) Arial

Con formato: Fuente: (Predeterminada) Arial

Con formato: Inglés (Estados Unidos)

Código de campo cambiado

Código de campo cambiado

Con formato: Fuente: (Predeterminada) Arial

Con formato: Fuente: (Predeterminada) Arial

Con formato: Fuente: (Predeterminada) Arial
Con formato: Sin Resaltar 
76 temperature, samples containing both only SSA or samples containing $75 \%$ of coal fly 77 ash and $25 \%$ of sewage sludge slag presented slow setting time. For samples cured at $78 \quad 80^{\circ} \mathrm{C}$, a rapid solidification was observed.

79 For alkali-activated binders based on binary systems of blast furnace slag/SSA, $31 \mathrm{MPa}$ 80 in compression was reached for samples with $20 \mathrm{wt} . \%$ of SSA activated with 6 mol. $\mathrm{kg}^{-1}$ $81 \mathrm{NaOH}$ and cured during 90 days [23]. Chakraborty et al. [24] assessed ternary systems 82 of SSA, quicklime and blast furnace slag activated with sodium hydroxide solution 83 obtaining the maximum compressive strength (31.3 MPa) after 28 curing days for mortar activated with $50 \%$ of $\mathrm{NaOH}$ solution, $20 \%$ of quicklime, $10 \%$ of blast furnace slag and $70 \%$ of SSA.

Studies related to MK-based geopolymeric mortars containing SSA are scarce [25]. After 7 curing days at room temperature, MK-based mortar containing 10 wt.\% of SSA presented similar compressive strength to mortar without SSA (about 28MPa). In the same study, the loss of compressive strength for MK-based mortar containing 20 wt.\% of SSA is reduced when compared to MK-based geopolymer [25].

Due to the $A$ waste with a significant concern in many countries over the growth of solid waste generation, a waste material with high potential application is the ash generated from the combustion of sewage sludge from wastewater treatment plants, well-known as sewage sludge ash (SSA) $[9,10]$. Its

Sewage sludge generation is estimated at anywhere from $0.1 \mathrm{~kg}$ up to $30.8 \mathrm{~kg}$ per population equivalent per year (kg/p.e/year) in European Union [11]. Incineration is an environmentally friendly alternative disposal method for sewage sludge and it has been considered to mitigate the effect of their increased volume, converting it into energy and fuel (Cies̈lik et al., 2015; Kelessidis and Stasinakis, 2012; Syed-Hassan et al., 2017; Yang et al., 2015). The incineration process reduces de-watered sewage sludge volume by approximately $90 \%$.

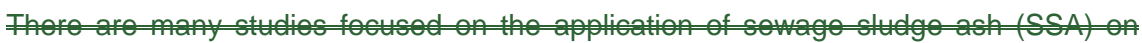
Portland cement mortars, bricks, ceramics and glass production (Baeza et al., 2014; Monzó- ah, 2003; Perez Carionetal, 2013; Smolet ah, 2015; Tagoet al, 2017; Yusufet al, 2012), The main components of the SSA are SiO ${ }_{2}, \mathrm{Al}_{2} \theta_{3}, \mathrm{Fe}_{2} \theta_{3}, \mathrm{GaO}, \mathrm{MgO}$ and $\mathrm{P}_{2} \mathrm{O}_{5}$. The presence of $\mathrm{SiO}_{2}$ and/or $\mathrm{Al}_{2} \mathrm{O}_{3}$ in amorphous state makes this waste material a potential pozzolanic material [12-15]. Due to its chemical composition, Ithere are many studies focused on the application of sewage sludge ash (SSA) on Portland cement mortars, bricks, ceramics and glass production $[16-21]$.
Con formato: Fuente: (Predeterminada) Arial

Con formato: Fuente: (Predeterminada) Arial

Con formato: Fuente: (Predeterminada) Arial

Con formato: Fuente: (Predeterminada) Arial

Con formato: Fuente: (Predeterminada) Arial

Con formato: Fuente: (Predeterminada) Arial

Con formato: Inglés (Estados Unidos)

Con formato: Fuente: (Predeterminada) Arial

Con formato: Inglés (Estados Unidos)

Con formato: Fuente: (Predeterminada) Arial

Con formato: Inglés (Estados Unidos)

Con formato: Fuente: (Predeterminada) Arial, Inglés (Estados Unidos) 
Although the SSA may exhibit a potential for use as a precursor due to its chemical composition, its use in geopolymeric binders is recent. Li and Poon (2017) studied the incorporation of sewage sludge ash and cathode ray tube funnel glass in Portland cement mortars. The cement was replaced by sewage sludge ash in three different proportions $(10,20$ and 30 wt.\%) and the sand was totally replaced by cathode ray tube funnel glass. The flexural strength was increased when $20 \mathrm{wt} . \%$ of cement was replaced by SSA, in comparison with standard Portland cement mortar. Moreover, the flexural strength was higher when compared to mortar containing fly ash or ground granulated blast furnace slag, which can be explained by a reduction in the effective water/binder ratio due to the high water absorption of SSA.

Although the SSA has the potential for use as a precursor due to its chemical composition, its use in geopolymeric binders is recent. The oxides as $\mathrm{Al}_{z} \underline{\mathrm{O}}_{3}, \mathrm{SiO}_{z}$-and GaO in the sewage sludge slag present substantial contribution in the poly-condensation of the amorphous phases in the coal fly ash based-geopolymers. However, these geopolymeric-mortars cured at room temperature present a slow hardening process; and in high temperature $\left(80^{\circ} \mathrm{C}\right)$, the results is not vet satisfactory [22]. Moreover, Yamaguchi and lkeda (2010) studied a geopolymeric material formed by a mixture of sewage sludge slag (SSS) and coal fly ash. The results showed that $\mathrm{Al}_{2} \mathrm{O}_{3}, \mathrm{SiO}_{z}$ and 6aO in the SSS contributed to the poly-condensation of the geopolymeric phases. However, mortar cured at room temperature presented a slow hardening process, and curing at $80^{\circ} \mathrm{C}$ was necessary to obtain better results the addition of SSA in a range of 20 wt.\% in metakaolin (MK) based-geopolymers cured at $65^{\circ} \mathrm{C}$ leads to a lower loss of compressive strength. Further, if the schedule curing is in a room temperature, the MK based-geopolymers containing $10 \mathrm{wt} . \%$ of SSA present similar compressive strength compared to the one with only MK. Nevertheless, the influence of the SSA on MK-based metakalolin only were studied in early stage of the curing time ( 1 to 7 days) [23].

Istuque et al. (2016) investigated the behaviour of the SSA on metakaolin basedgeopolymer for very short curing time (from 1 to 7 days). The results showed that a replacement of metakaolin ( 20 wt. \%) by SSA leads to a lower loss of compressive strength in geopolymer cured at elevated temperature $\left(65^{\circ} \mathrm{C}\right)$. Besides, geopolymers containing 10 wt.\% of SSA cured at room temperature presented similar compressive strength when compared to the metakaolin (MK)-based geopolymer with up to 7 curing days.
Con formato: Fuente: (Predeterminada) Arial

Código de campo cambiado

Con formato: Fuente: (Predeterminada) Arial

Con formato: Fuente: (Predeterminada) Arial, Inglés (Estados Unidos)

Con formato: Inglés (Estados Unidos)

\section{Código de campo cambiado}

Con formato: Fuente: (Predeterminada) Arial

Con formato: Fuente: (Predeterminada) Arial

Con formato: Fuente: (Predeterminada) Arial 
In the case of high calcium content Aalkali-activated binders, the addition of SSA (20 wt. \%) did not prejudice the mechanical properties of binary system of blast furnace slag (BFS) and SSA obtaining a maximum compressive strength of $31 \mathrm{MPa}$ [24]. Further, in a ternary system of SSA, quicklime (QL) and BFS in the proportion of 7:2:1 present satisfactory results as containing a binary system of blast furnace slag/SSA were studied by Tashima et al. (2017) and Chakraborty et al. (2017)..a maximum bulk density (1810 $\pm 6 \mathrm{~kg} \mathrm{~m}^{-3}$ ), a minimum apparent porosity $(11.1 \%)$, optimum compressive strength (31.3 $\pm 1.5 \mathrm{MPa})$, flexural strength $(3.9 \pm 0.25)$ and flexural modulus (1.61 $\pm 0.065 \mathrm{GPa})$ [25]. Between this and that, The obtained results showed thatthat SSA the SSA is a potential sustainable precursor in this type of binder.

As can be observed, scientific knowledge related to the use of SSA as a precursor in the production of alkali-activated binders is very limited, and $_{1}$ systematic studies on this topic should be performed. Hence, this study aims to assess the long-term influence of SSA in MK-based geopolymer, as well as the influence of the $\mathrm{SiO}_{2} / \mathrm{Na}_{2} \mathrm{O}$ molar ratio and curing conditions for SSA/MK-based geopolymers. Thereby, X-ray diffraction (XRD), thermogravimetric analysis (TGA), Fourier transform infrared spectroscopy (FTIR) and scanning electron microscopy (SEM) analyses on pastes and compressive strength tests on geopolymeric mortars were carried out.

\section{Experimental}

\subsection{Materials}

Metakaolin (MK) supplied by Metacaulim do Brasil ${ }^{\mathrm{TM}}$ was the main aluminosilicate source used in this study. The SSA used as non-conventional aluminosilicate precursor was produced by an auto-combustion process of sewage sludge from a sewage treatment plant (Serviço Municipal Autônomo de Água e Esgoto - SEMAE, in São José do Rio Preto city - São Paulo, Brazil). The chemical compositions of both MK and SSA, determined by X-ray fluorescence (XRF), are given in Table 1. Both materials, MK and $\underline{\mathrm{SSA}}$, presented a significant content of $\mathrm{SiO}_{2}$ and $\mathrm{Al}_{2} \mathrm{O}_{3}$ as main oxides, which are elementary oxides to the development of the geopolymer structure.with $58.39 \mathrm{wt} . \%$ and $32.72 \mathrm{wt} . \%$ of $\mathrm{SiO}_{2}$ and $35.47 \mathrm{wt} . \%$ and $20.72 \mathrm{wt} . \%$ of $\mathrm{Al}_{2} \mathrm{\theta}_{3}$ for MK and SSA, respectively. As-received MK was used in this study and according to the particle size analyser (Mastersize 2000 from Malvern Instruments), this material present $d(50)$ of $18.16 \mu \mathrm{m}, \mathrm{d}(90)$ of $53.96 \mu \mathrm{m}$ and a mean particle diameter of $23.90 \mu \mathrm{m}$. On the other hand, SSA was ground in a ball mill for 50 minutes before its use obtaining d(50) of 11.17 $\mu \mathrm{m}, \mathrm{d}(90)$ of $52.45 \mu \mathrm{m}$ and a mean particle diameter of $20.28 \mu \mathrm{m}$.

\section{Código de campo cambiado}

Con formato: Fuente: (Predeterminada) Arial

Con formato: Fuente: (Predeterminada) Arial

Con formato: Fuente: (Predeterminada) Arial

Código de campo cambiado

Con formato: Fuente: (Predeterminada) Arial

Con formato: Fuente: (Predeterminada) Arial

Código de campo cambiado

Con formato: Fuente: (Predeterminada) Arial

Con formato: Fuente: (Predeterminada) Arial 
A siliceous sand from Castilho city (São Paulo - Brazil) with a fineness modulus of 2.05 and specific gravity of $2.67 \mathrm{~g} / \mathrm{cm}^{3}$ was used in the geopolymeric mortars. An inert filler (siliceous material) with particle diameter lower than $53 \mu \mathrm{m}$ was used for comparison. Sodium hydroxide (98\% purity) and sodium silicate solution (8.9\% $\mathrm{Na}_{2} \mathrm{O}, 29.7 \% \mathrm{SiO}_{2}$ and $61.40 \% \mathrm{H}_{2} \mathrm{O}$ ) were used in the preparation of the alkaline activating solution.

Table 1 - Chemical Compositions (\%, in mass) of metakaolin (MK) and sewage sludge ash (SSA).

\begin{tabular}{ccccccccccccc}
\hline $\begin{array}{c}\text { Oxides } \\
(\%)\end{array}$ & $\mathrm{SiO}_{2}$ & $\mathrm{Al}_{2} \mathrm{O}_{3}$ & $\mathrm{Fe}_{2} \mathrm{O}_{3}$ & $\mathrm{P}_{2} \mathrm{O}_{3} \mathrm{P}_{2} \mathrm{O}_{5}$ & $\mathrm{CaO}$ & $\mathrm{SO}_{3}$ & $\mathrm{TiO}_{2}$ & $\mathrm{MgO}$ & $\mathrm{K}_{2} \mathrm{O}$ & $\mathrm{Na}_{2} \mathrm{O}$ & Others & $\mathrm{LOI}$ \\
\hline $\mathrm{SSA}$ & 38.28 & 20.72 & 11.27 & 7.28 & 5.51 & 4.18 & 3.73 & 1.91 & 0.73 & 0.70 & 1.97 & 3.72 \\
\hline $\mathrm{MK}$ & 58.39 & 35.47 & 2.71 & - & 0.01 & - & 1.51 & 0.3 & 1.44 & - & 0.07 & 0.10 \\
\hline
\end{tabular}

\subsection{Geopolymeric mortar preparation}

Table 2 shows the mix proportions for all assessed samples. For all cases the water/binder ratio, sand/binder ratio and concentration of $\mathrm{Na}^{+}\left(\mathrm{mol}\right.$ of $\mathrm{Na}_{3}^{+}$per $-\mathrm{kg}^{-1}$ of water, mol. $\mathrm{kg}^{-1}$ ) were fixed at 0.6, 2.5 and 8.0, respectively. The binder was the sum of MK and SSA and the water content was the sum of water in sodium silicate solution and the added tap water to get the 0.6 water/binder ratio. The concentration of $\mathrm{Na}^{+}$was fixed at $8.0 \mathrm{~mol}^{\mathrm{kg}}{ }^{-1}$ due preliminary studies performed by authors where the compressive strength of SSA/MK-based geopolymeric mortars was assessed for different

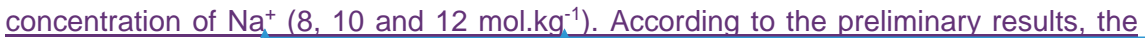
increment on the $\mathrm{Na}^{+}$concentration reduces the compressive strength of mortars in 36\% for $10 \mathrm{~mol}^{\mathrm{kg}}{ }^{-1}$ and $60 \%$ for $12 \mathrm{~mol}_{\mathrm{kg}}^{-1}$.

The influence of curing conditions (room temperature curing at $25^{\circ} \mathrm{C}$ with $\mathrm{RH} \sim 95 \%$ and thermal curing at $65{ }^{\circ} \mathrm{C}$ with $\left.\mathrm{RH} 95 \%\right)$ and the influence of $\mathrm{SiO}_{2} / \mathrm{Na}_{2} \mathrm{O}$ molar ratio $(0.8$ and 1.6) were assessed for the MK/SSA system. Both parameters are considered key factors in the geopolymerization process [26-28].
Con formato: Fuente: (Predeterminada) Arial

Con formato: Fuente: (Predeterminada) Arial Código de campo cambiado

Con formato: Superíndice

Con formato: Superíndice

Con formato: Superíndice

Con formato: Superíndice

Con formato: Superíndice

Con formato: Superíndice

Con formato: Superíndice

Con formato: Superíndice

Con formato: Superíndice

Con formato: Fuente: (Predeterminada) Arial

Con formato: Fuente: (Predeterminada) Arial

Con formato: Fuente: (Predeterminada) Arial 
The nomenclature of geopolymeric samples is as follows: $\mathbf{x S S A} \mathbf{8 - z} \mathbf{W}$, where $\mathbf{x}$ represents the percentage of SSA (0 or 10), "8" represents the sodium molality (8 mol.kg$\left.{ }^{1}\right), \mathbf{z}$ is the $\mathrm{SiO}_{2} / \mathrm{NaO}_{2}$ molar ratio (0.8 or 1.6) and $\mathbf{W}$ is associated with the curing condition ( $R$ for room temperature and B for thermal bath curing).

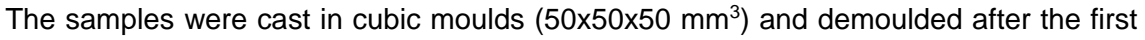
24 hours. Specimens were maintained in the respective curing conditions until the compressive strength test age $(1,3,7,14,28,90$ and 180 days). The compressive strength tests on the geopolymeric mortars were performed in an EMIC Universal machine with a 200 ton load limit and during the test was maintained a loading rate of $0.25 \pm 0.05 \mathrm{MPa} / \mathrm{s}$.

Table 2. Mix proportions for assessed samples.

\begin{tabular}{|c|c|c|c|c|c|c|c|}
\hline \multirow{2}{*}{ Geopolymeric mortar } & MK & SSA & \multirow{2}{*}{ Curing condition } & $\mathrm{SiO}_{2} / \mathrm{Na}_{2} \mathrm{O}$ & water/binder & sand/binder & \multirow{2}{*}{$\frac{\mathrm{Na}^{+}}{\left(\mathrm{mol}^{\left.-\mathrm{kg}^{-1}\right)}\right.}$} \\
\hline & \multicolumn{2}{|c|}{$\%$ mass } & & (molar ratio) & \multicolumn{2}{|c|}{ (mass ratio) } & \\
\hline 0SSA 8-0.8 R & 100 & 0 & Room temperature & 0.8 & 0.6 & 2.5 & 8 \\
\hline 0SSA 8-0.8 B & 100 & 0 & Thermal bath & 0.8 & 0.6 & 2.5 & 8 \\
\hline 10SSA 8-1.6 R & 90 & 10 & Room temperature & 1.6 & 0.6 & 2.5 & 8 \\
\hline 10SSA 8-1.6 B & 90 & 10 & Thermal bath & 1.6 & 0.6 & 2.5 & 8 \\
\hline
\end{tabular}

\subsection{Geopolymeric paste preparation}

Pastes with the same mix proportions and curing conditions as geopolymeric mortars were produced to assess the geopolymerization reaction. X-ray diffraction (XRD) patterns for both raw materials and geopolymeric pastes were obtained using a Shimadzu XRD-6000 system. The tests were performed using a current intensity of 40 $\mathrm{mA}$ at $30 \mathrm{kV}$, a step angle of $0.02^{\circ}$, a step time of $1.20 \mathrm{~s} / \mathrm{step}$, with $\mathrm{Cu}-\mathrm{K} \alpha$ radiation and a Ni filter in $2 \theta$ range $5-60^{\circ}$.

A Mettler Toledo TGA850 thermobalance was used to analyze pastes by thermogravimetry (TGA). The parameters employed in TGA were: temperature range of $35-600{ }^{\circ} \mathrm{C}$ with a heating rate of $10^{\circ} \mathrm{C} \cdot \mathrm{min}^{-1}$ and a $\mathrm{N}_{2}$ atmosphere $\left(75 \mathrm{~mL} \cdot \mathrm{min}^{-1} \mathrm{flow}\right)$. The samples were tested in sealed aluminum crucibles $(100 \mu \mathrm{L})$ with a pinhole in the lid. FTIR analysis was performed using a BRUKER TENSOR 27 in the wavenumber range of 400 to $4000 \mathrm{~cm}^{-1}$. Scanning electron microscopy (SEM) images of fractured surface pastes were obtained using a ZEISS model EVO LS15.
Con formato: Fuente: (Predeterminada) Arial 


\section{Results and Discussion}

\subsection{Compressive strength test}

The compressive strength test was performed to assess the influence of SSA on longterm mechanical development of SSA/MK-based geopolymers. The results for both $\mathrm{SiO}_{2} / \mathrm{Na}_{2} \mathrm{O}$ molar ratios cured at $25^{\circ} \mathrm{C}$ are depicted in Fig. 1. For both cases, an increase in compressive strength over time was observed. However, the samples with the highest $\mathrm{SiO}_{2} / \mathrm{Na}_{2} \mathrm{O}$ molar ratio (1.6) displayed, in general, higher compressive strength for all curing ages. Greater compressive strength provided by high $\mathrm{SiO}{ }_{2} / \mathrm{Na}_{2} \mathrm{O}$ molar ratio (1.9) was also pointed out by Cheng et al. (2015). who studied the influence of the $\mathrm{SiO}_{2} / \mathrm{Na}_{2} \mathrm{O}$ molar ratios on waste catalyst/MK-based geopolymer. The increasing of the $\mathrm{SiO}_{2} / \mathrm{Na}_{2} \underline{\mathrm{O}}$ molar ratio increases the dissolution rate of the aluminosilicates moleculesnetwork into monomer species, which interact with others yielding large tridimensional molecules, which precipitates in the form of amorphous sodium aluminosilicate hydrate (N-A-S-H) gels, then, composing a harder and compacted structure [26,29-31].

In addition, the samples of OSSA and 10SSA with the highest $\mathrm{SiO}_{2} / \mathrm{Na}_{2} \mathrm{O}$ molar ratio reached their maximum levels at about 48-50 $\mathrm{MPa}$ at 7 and 14 days of curing, respectively. The reference sample (OSSA) reached a maximum compressive strength of 31.2 and 50.3 MPa at 180 days of curing to the lowest (0.8) and the highest (1.6) $\mathrm{SiO}_{2} / \mathrm{Na}_{2} \mathrm{O}$ molar ratio, respectively. The sample containing SSA (10SSA) with the lowest $\mathrm{SiO}_{2} / \mathrm{Na}_{2} \mathrm{O}$ molar ratio (0.8) reached a maximum compressive strength of $26.4 \mathrm{MPa}$ at 180 days, which was slightly lower than the reference sample value (31.2 MPa) at 180 days of curing.

However, the sample 10SSA with the highest $\mathrm{SiO}_{2} / \mathrm{Na}_{2} \mathrm{O}$ molar ratio reached a very similar compressive strength after 14 days of curing compared to the sample 0SSA with the same $\mathrm{SiO}_{2} / \mathrm{Na}_{2} \mathrm{O}$ molar ratio and time of curing; the value reached was $50.8 \mathrm{MPa}$ at 180 days of curing.

As can be observed, SSA affects, mainly,_-the hardening process of samples with both $\mathrm{SiO}_{2} / \mathrm{Na}_{2} \mathrm{O}$ molar ratios. The geopolymerization reaction and the compressive strength development in the first curing days at $25{ }^{\circ} \mathrm{C}$ were retarded. For the lowest $\mathrm{SiO}_{2} / \mathrm{Na}_{2} \mathrm{O}$ molar ratio, the sample 0SSA showed at least $90 \%$ of the final compressive strength after only 7 days of curing that it reached after 180 days of curing, while the sample 10SSA exhibited at least $90 \%$ of its final compressive strength at 180 days after only-14 days of curing. For this curing temperature $\left(25^{\circ} \mathrm{C}\right)$, SSA reactivity did not compensate for

\section{Código de campo cambiado}

Con formato: Fuente: (Predeterminada) Arial

Con formato: Fuente: (Predeterminada) Arial

Con formato: Fuente: (Predeterminada) Arial

\section{Código de campo cambiado}

Con formato: Fuente: (Predeterminada) Arial, Inglés (Estados Unidos)

Con formato: Fuente: (Predeterminada) Arial

Con formato: Fuente: (Predeterminada) Arial 
the reduction of $10 \%$ of $\mathrm{MK}$ content. For the highest $\mathrm{SiO}_{2} / \mathrm{Na}_{2} \mathrm{O}$ molar ratio, the 0SSA sample reached $90 \%$ of its final strength at 180 days of curing after only 1 day of curing. In addition, when 10\% replacement (10SSA) was carried out, this condition was only achieved after 14 days, indicating that SSA strongly affects the first stage of the geopolymerization process. Although, aA similar delaying effect was reported to fly ash due to an Al-rich gel transformation into Si-rich aluminosilicate gel, such reason is not clear to explain the delaying effect of SSA [32].

To verify the influence of the SSA in the hardening of the MK based-geopolymer with the $\underline{\underline{\text { highest } \mathrm{SiO}_{2}}} \underline{\underline{\mathrm{Na}_{2}}} \underline{\underline{\mathrm{O}} \text { molar ratio, a compressive strength test was carried out in the MK }}$ based-geopolymer mortar with 10 wt.\% of the MK replaced by an inert filler (siliceous material) with particle diameter tower thanunder $53 \mu \mathrm{m}$. The replacement of MK by an inert filler provided a parameter to compare the result displayed by the sample 10SSA.

The mix dosage was maintained in the same conditions as the sample 10SSA presented in Table 2. A compressive strength test was performed with 1 day of curing at both temperatures $\left(25^{\circ} \mathrm{C}\right.$ and $\left.65^{\circ} \mathrm{C}\right)$. - The mortars cured at $25^{\circ} \mathrm{C}$ and $65^{\circ} \mathrm{C}$ displayed compressive strengths of $46.7 \pm 1.3 \mathrm{MPa}$ and $43.5 \pm 1.6 \mathrm{MPa}$, respectively. The results showed that replacement of the MK in 10 wt.\% by inert filler did not result in a delay in the hardening of the sample, confirming the delay effect of SSA (10SSA mortars cured during 1 day at $25^{\circ} \mathrm{C}$ and $65^{\circ} \mathrm{C}$ displayed compressive strengths of $25.7 \pm 2.1 \mathrm{MPa}$ and 20.8 $\pm 2.3 \mathrm{MPa}$, respectively)...

Therefore, it was clear that the chemical composition of the SSA was the main factor in explaining the delay in the geopolymer reaction shown by the 10SSA system. Probably the presence of $\mathrm{P}_{2} \mathrm{O}_{5}$ or $\mathrm{SO}_{3}$ are generating this delaying effect. Although a delay was reported in the first days of curing of the samples with the highest $\mathrm{SiO}_{2} / \mathrm{Na}_{2} \underline{\underline{\mathrm{O}} \text { molar ratio, }}$ the compressive strength of the sample 10SSA displayed behaviour similar to that of the sample OSSA after 14 days of curing, when both were cured at $25^{\circ} \mathrm{C}$. This behaviour

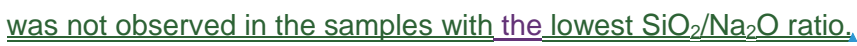

Fig. 2 shows the compressive strength of samples activated by means of both $\mathrm{SiO}_{2} / \mathrm{Na}_{2} \mathrm{O}$ molar ratios and cured at $65^{\circ} \mathrm{C}$. As reported for the samples cured at $25^{\circ} \mathrm{C}$, the samples with the highest $\mathrm{SiO}_{2} / \mathrm{Na}_{2} \mathrm{O}$ molar ratio cured at $65{ }^{\circ} \mathrm{C}$ also developed greater compressive strength at all curing times. However, the compressive strength of the samples cured at $65^{\circ} \mathrm{C}$ decreased over time, at least after 14 days, in contrast to the samples cured at $25^{\circ} \mathrm{C}$, which presented increasing compressive strength at least until 180 days of curing. The compressive strength loss in samples cured at high temperature is also reported by Zhang et al. (2015). These authors pointed out this fact as a
Código de campo cambiado

Con formato: Fuente: (Predeterminada) Arial

Con formato: Fuente: (Predeterminada) Arial

Con formato: Fuente: (Predeterminada) Arial

Código de campo cambiado

Con formato: Fuente: (Predeterminada) Arial

Con formato: Subíndice

Con formato: Subíndice

Con formato: Subíndice

Con formato: Fuente: (Predeterminada) Arial

Código de campo cambiado

Con formato: Fuente: (Predeterminada) Arial

Con formato: Fuente: (Predeterminada) Arial

Con formato: Fuente: (Predeterminada) Arial 
thermodynamic issue: the gel-type products from the metakaolin geopolymerization reaction are meta-stable and the environment with an elevated humidity and high temperature can produce the transformation of these amorphous products into more crystal-ordered structures (zeolite structures)_[33]. Furthermore, the elevated temperature increases the early compressive strength, on the other hand, the accelerated consolidation of the structure likely does not result in good quality gels [34].

The samples of OSSA and 10SSA with the lowest $\mathrm{SiO}_{2} / \mathrm{Na}_{2} \mathrm{O}$ molar ratio cured at $65^{\circ} \mathrm{C}$ reached a maximum compressive strength of $29.2 \mathrm{MPa}$ at 3 days of curing and 22.6 MPa at 14 days of curing, respectively. In that case, the replacement of MK by SSA in 10 wt.\% decreased the maximum compressive strength reached by the OSSA geopolymer by $23 \%$. However, the maximum compressive strengths reached by samples with the highest $\mathrm{SiO}_{2} / \mathrm{Na}_{2} \mathrm{O}$ molar ratio cured at $65^{\circ} \mathrm{C}$ were $50.6 \mathrm{MPa}$ at 1 day of curing and 41.0 MPa at 7 days of curing, respectively for 0SSA and 10SSA mixtures, which resulted in slightly lower compressive strength reduction (19\%) when compared to $0.8 \mathrm{SiO}_{2} / \mathrm{Na}_{2} \mathrm{O}$ molar ratio.

The loss of compressive strength, in percentage, to the samples with the lowest $\mathrm{SiO}_{2} / \mathrm{Na}_{2} \mathrm{O}$ molar ratio until 180 days of curing, in relation to the maximum compressive strength reached, was 38\% and 29\% for the samples of 10SSA and OSSA, respectively. The loss of compressive strength was greater in the presence of SSA. However, this behaviour was different from the samples with the highest $\mathrm{SiO}_{2} / \mathrm{Na}_{2} \mathrm{O}$ molar ratio. The presence of SSA in the geopolymer decreased the loss of compressive strength. The sample containing SSA (10SSA) presented a loss of compressive strength of $44 \%$ while the samples with only MK (OSSA) presented a loss of compressive strength of $51 \%$, both of them after 180 days of curing. This behaviour of loss of compressive strength over time shown by the SSA in MK based-geopolymer with curing at $65^{\circ} \mathrm{C}$ was also pointed out in a previous study of short-term curing of the SSA/MK based-geopolymer [2325].

The same retarding behaviour in geopolymer reaction pointed out for the samples cured at $25{ }^{\circ} \mathrm{C}$ occurred in the samples cured at $65^{\circ} \mathrm{C}$. With respect to the lowest $\mathrm{SiO}_{2} / \mathrm{Na}_{2} \mathrm{O}$ molar ratio, the compressive strength of the mortar 10SSA was approximately $24 \%$ less than the compressive strength of mortar OSSA at both temperatures at 1 day of curing. However, when the $\mathrm{SiO}_{2} / \mathrm{Na}_{2} \mathrm{O}$ molar ratio was increased to 1.6 , the compressive strengths of the mortars 10SSA cured at both temperatures, when compared to mortars OSSA values, were approximately $43 \%$ and $59 \%$ lower on the first day of curing at $25{ }^{\circ} \mathrm{C}$ and $65^{\circ} \mathrm{C}$, respectively.
Código de campo cambiado

Con formato: Fuente: (Predeterminada) Arial

Código de campo cambiado

Con formato: Fuente: (Predeterminada) Arial, Inglés (Estados Unidos)

Con formato: Espacio Después: 0 pto

Con formato: Fuente: (Predeterminada) Arial

Con formato: Fuente: (Predeterminada) Arial

Con formato: Fuente: (Predeterminada) Arial 
To verify the influence of the SSA in the hardening of the MK based-geopolymer with the highest $\mathrm{SiO}_{2} \mathrm{Avaz}_{2} \mathrm{O}$ molar ratio, a compressive strength test was carried out in the MKK based-geopolymer mortar with 10 wt \% of the MK replaced by an inert filler (siliceous

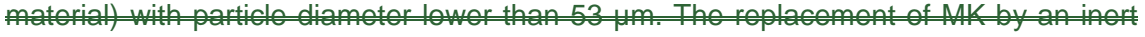
filler provided a parameter to compare the result displayed by the sample 10SSA.

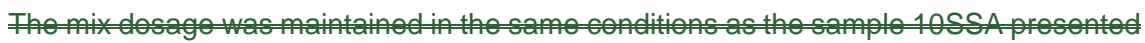
in z. A compressive strength test was performed with 1 day of curing at both temperatures $\left(25^{\circ} \mathrm{C}\right.$ and $\left.65^{\circ} \mathrm{C}\right)$. The mortars cured at $25^{\circ} \mathrm{C}$ and $65^{\circ} \mathrm{C}$ displayed compressive strengths of $46.7 \pm 1.3 \mathrm{MPa}$ and $43.5 \pm 1.6 \mathrm{MPa}$, respectively. The results showed that replacement of the MK in 10 wt.\% by inert filler did not result in a delay in the hardeng of the sample.

Therefore, it was clear that the chemical composition of the SSA was the main factor in

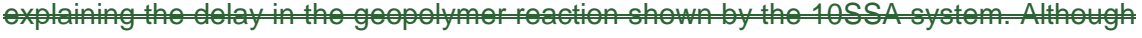
a delay was reported in the first days of curing of the samples with the highest $\operatorname{SiO}_{2} / \mathrm{Na}_{2} \mathrm{O}$

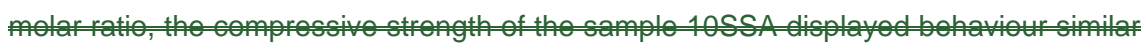
to that of the sample OSSA after 14 days of curing, when both were cured at $25^{\circ} \mathrm{C}$. This behaviour was not observed in the samples with lowest $\mathrm{SiO} \mathrm{O}_{2} / \mathrm{Na}_{2} \mathrm{O}$ ratio. 


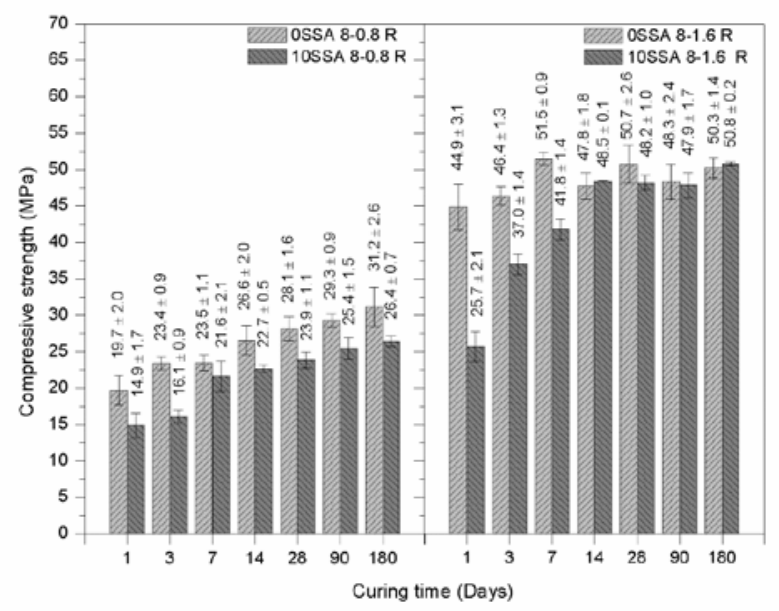

Con formato: Justificado, Interlineado: 1,5 líneas, No conservar con el siguiente

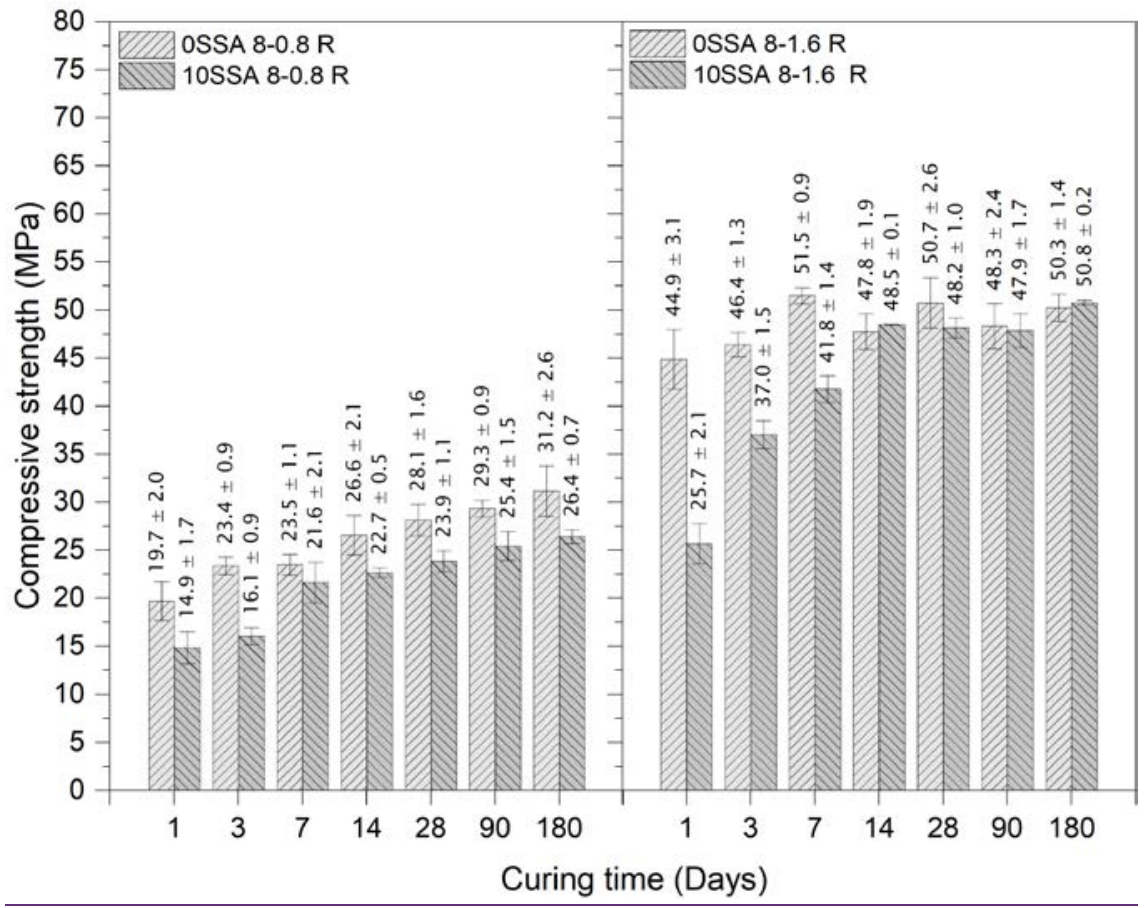

Fig. 1. Compressive strength development of metakaolin-based geopolymers with $\left[\mathrm{Na}^{+}\right]$

$=8$ mol. $\mathrm{kg}^{-1}$ and for both $\mathrm{SiO}_{2} / \mathrm{Na}_{2} \mathrm{O}$ molar ratios (0.8 and 1.6). Reference (0SSA) 

room temperature $\left(R, 25^{\circ} \mathrm{C}\right)$. 


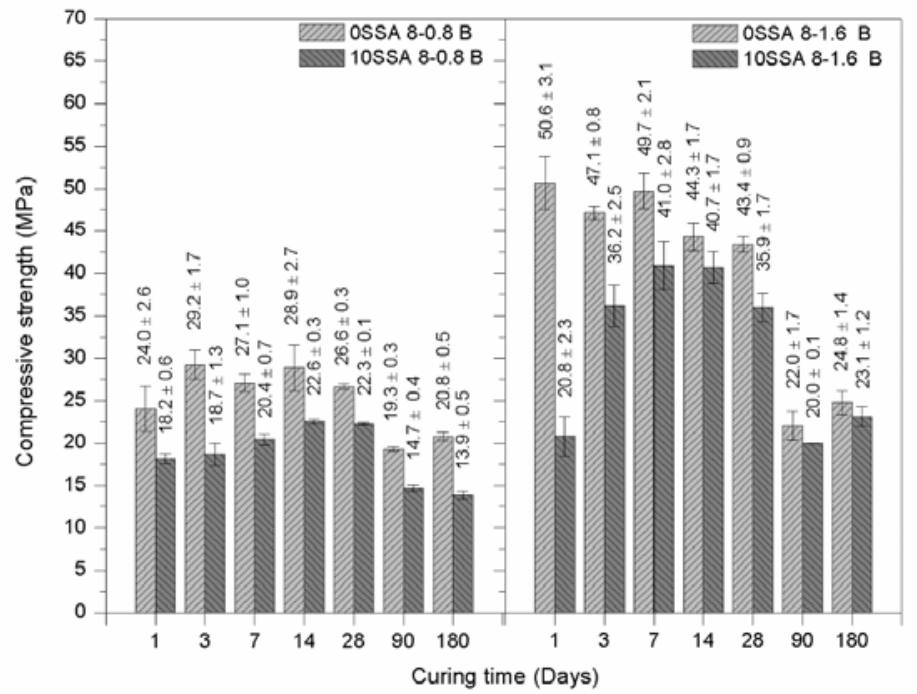

363

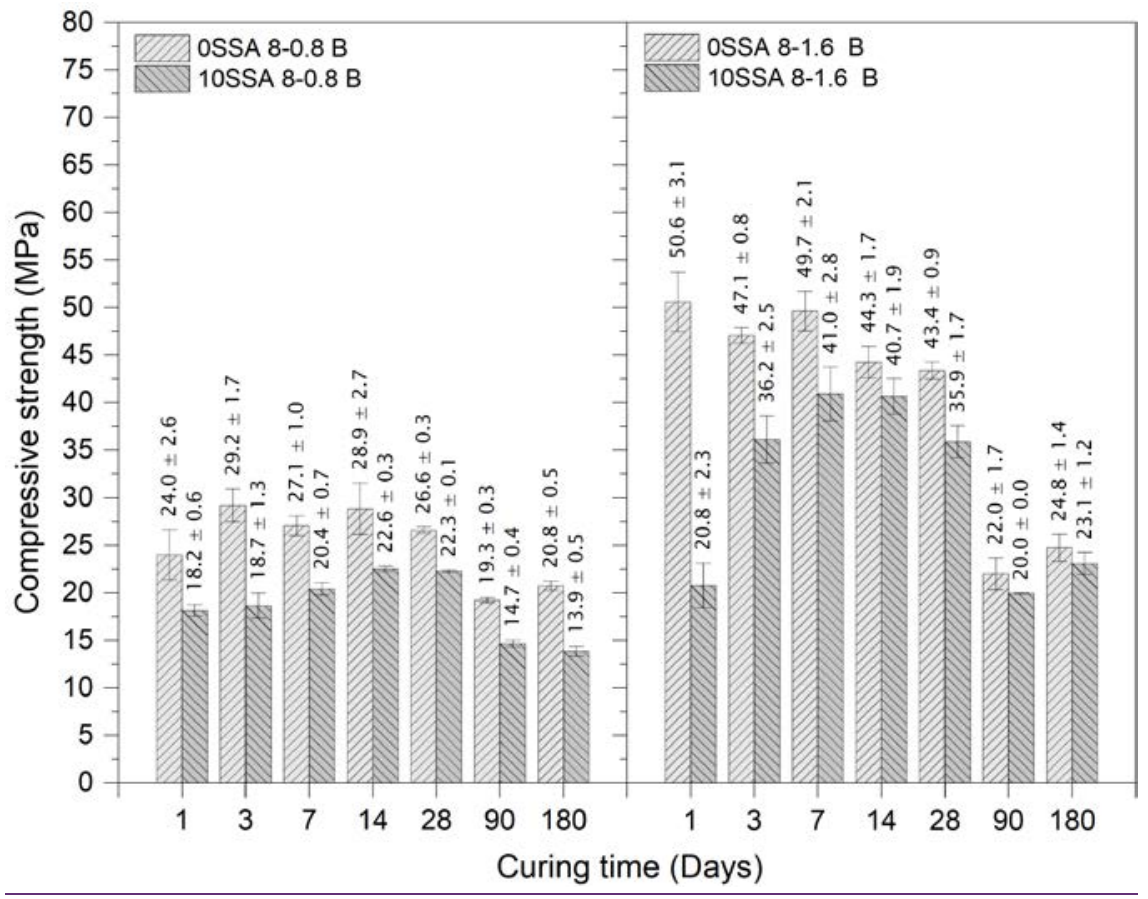

Fig. 2. Compressive strength development metakaolin-based geopolymer with $\left[\mathrm{Na}^{+}\right]=$ 
samples and samples with 10 wt. $\%$ of SSA (10SSA) were cured in a thermal bath at $65^{\circ} \mathrm{C}(\mathrm{B})$

\subsection{X-rays RDdiffraction analyses}

XRD analyses were carried out on all mix proportions cured for 7 days in a thermala thermal bath and at 90 days for both curing conditions (room temperature and thermal bath). The diffraction patterns of the SSA/MK geopolymers pastes with $\mathrm{SiO}_{2} / \mathrm{Na}_{2} \mathrm{O}$ ratio equal to 0.8 and 1.6,1.6, respectively are shown in Fig.ures 3 and 4.

A baseline deviation can be noted in the range $16-32^{\circ}$ and $18-32^{\circ}$, respectively, in the XRD pattern for both raw materials, MK and SSA, which is characteristic of the presence of an amorphous phase [35,36]. However, the XRD patterns of pastes also showed a baseline deviation in most of the SSA/MK based-geopolymer systems $\left(16^{\circ}-38^{\circ}\right)$, which can be attributed to the occurrence of the geopolymeric reaction and, consequently, the formation of geopolymeric gel (N-A-S-H gel) $[31,37,38]$. The exceptions are the samples with 90 days of curing at $65{ }^{\circ} \mathrm{C}$ that presented a slight deviation of the baseline due to a minor content of amorphous phases. A less content of amorphous phases in this sample could be associated with, which is attributed to a the crystallization process of the amorphous phases. For these samples, the formation of $\mathrm{Na}$ P-type zeolite

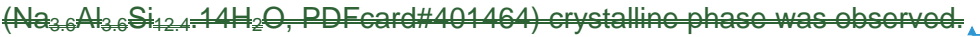

FThe transitionformation of the amorphous gel into the ordered structure (crystalline phases) explains the loss of compressive strength of the sample cured at sealed high temperature environmental, which cause microstructure changes and internal stress [39]. Then, as can be seen in the Fig. 2, such transition might had occurred mostly after the first 14 days of curing. For these samples, the formation of $\mathrm{Na} P$-type zeolite $\left(\mathrm{Na}_{3.6} \mathrm{Al}_{3.6} \mathrm{Si}_{12.4} .14 \mathrm{H}_{2} \mathrm{O}\right.$, PDFcard\#401464) crystalline phase was observed.

The elevated temperature curing triggers an acceleration of the geopolymerization reaction; however, it also activates the crystallization of the gel for a longer time. Such behaviour can be seen-was observed, primarily, in the compressive strength of the sample 0SSA with the highest $\mathrm{SiO}_{2} / \mathrm{Na}_{2} \mathrm{O}$ molar ratio, which reached a maximum in 1 day of curing. Due to the meta-stability of amorphous phases, a loss in compressive strength over time occurred. At 90 days of curing, the sample 10SSA with the lowest $\mathrm{SiO}_{2} / \mathrm{Na}_{2} \mathrm{O}$ molar ratio cured at $65{ }^{\circ} \mathrm{C}$, exclusively, presented, in addition to $\mathrm{Na}$ P-types
Con formato: Fuente: (Predeterminada) Arial

Con formato: Inglés (Reino Unido)

Código de campo cambiado

Código de campo cambiado

Con formato: Fuente: (Predeterminada) Arial 
zeolites, FAU-type zeolite $\left(\mathrm{Na}_{2} \mathrm{Al}_{2} \mathrm{Si}_{4} \mathrm{O}_{12} .8 \mathrm{H}_{2} \mathrm{O}\right.$, PDFcard\#391380) as a new crystalline phase. According to Pal et al. (2013), Tthe formation of FAU-type zeolite is favored in the alkaline activation reaction mainly for alkaline solutions with a low $\mathrm{SiO}_{2} / \mathrm{Na}_{2} \mathrm{O}$ ratio [40]. Crystalline phases such as muscovite $\left(\left(\mathrm{KAI}_{3} \mathrm{Si}_{3} \mathrm{O}_{10}(\mathrm{OH})_{2}, \mathrm{PDF}\right.\right.$ card\#210993), quartz $\left(\mathrm{SiO}_{2}, \mathrm{PDF}\right.$ card\#331161), and anhydrite $\left(\mathrm{CaSO}_{4}, \mathrm{PDF}\right.$ card\#371496) present in SSA/MK geopolymer are from the MK and SSA mineralogy composition. Kaolinite $\left(\mathrm{Al}_{2} \mathrm{Si}_{2} \mathrm{O}_{5}(\mathrm{OH})_{4}\right.$, PDFcard\#140164) and hematite $\left(\mathrm{Fe}_{2} \mathrm{O}_{3}, \mathrm{PDF}\right.$ card\#130534) appear only in the diffraction of the MK and SSA, respectively. Neither of the samples with 90 days of curing at $25^{\circ} \mathrm{C}$, OSSA and 10SSA, presented a formation of new crystalline phases. That behaviour is consistent with the compressive strength development of the samples cured at room temperature showed in the Fig. 1, which did not present any loss of compressive strength.
Código de campo cambiado

Con formato: Fuente: (Predeterminada) Arial Código de campo cambiado

Con formato: Fuente: (Predeterminada) Arial

Con formato: Fuente: (Predeterminada) Arial

Con formato: Fuente: (Predeterminada) Arial 


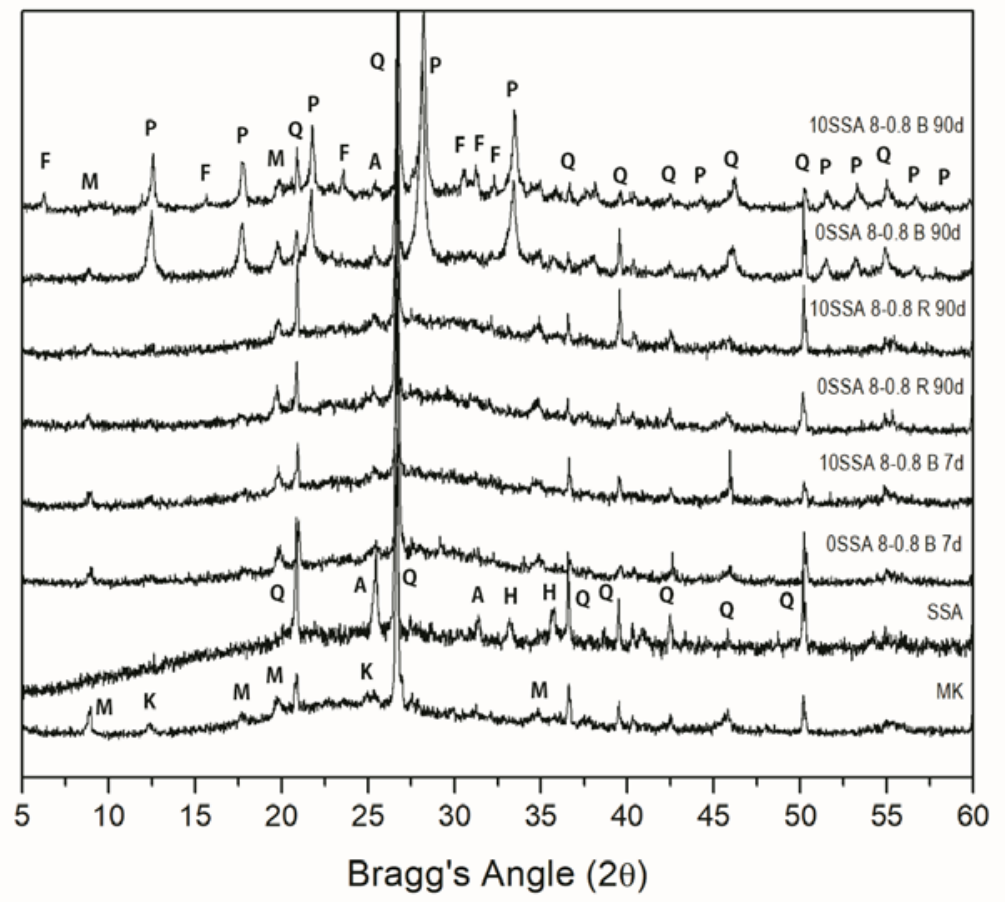




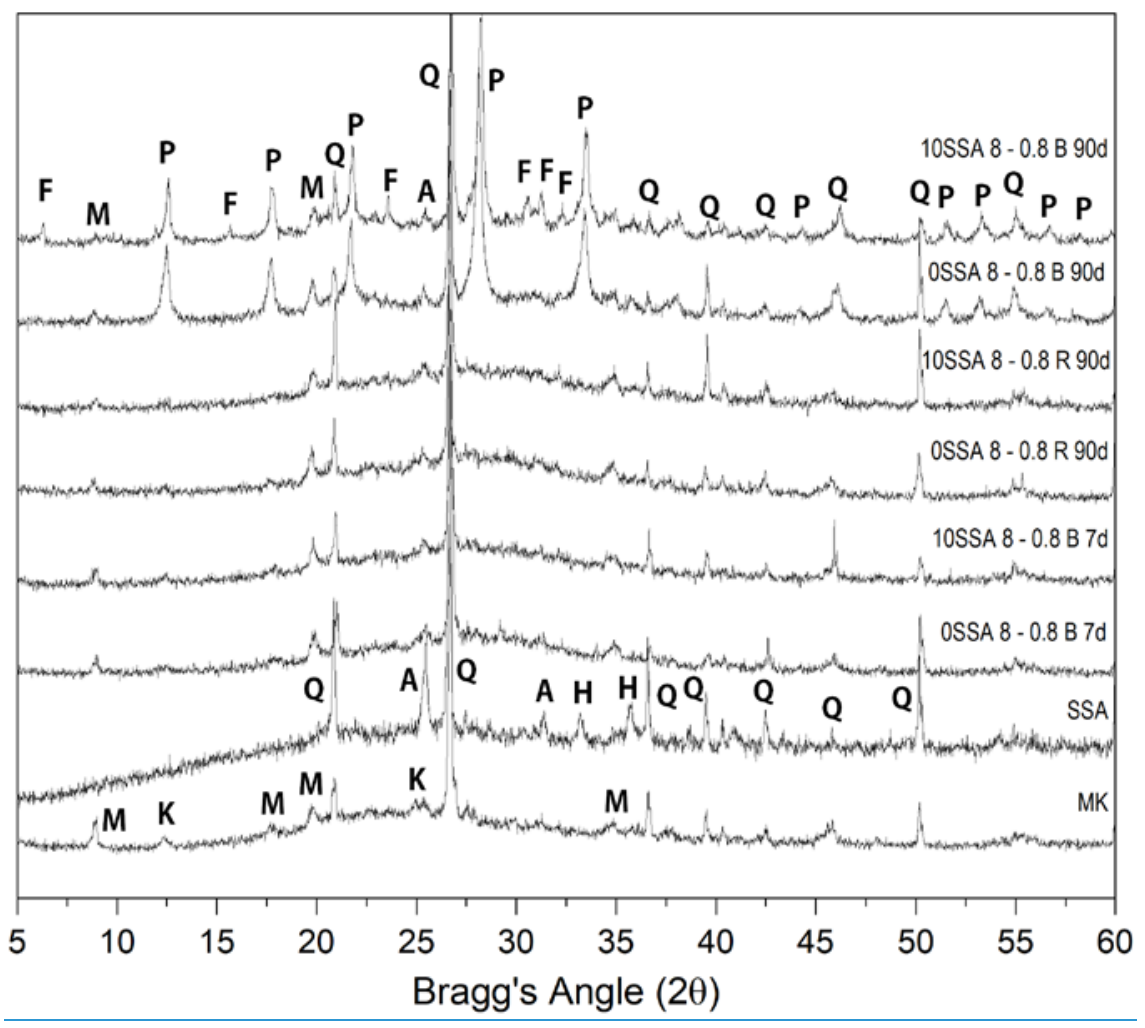

Fig. 3. XRD patterns of SSA/MK geopolymers with a $\mathrm{SiO}_{2} / \mathrm{Na}_{2} \mathrm{O}$ molar ratio of 0.8 (Key: F - FAU-type zeolite; K - kaolinite; M - Muscovite; P - Na P-type zeolite; Q - Quartz; A 


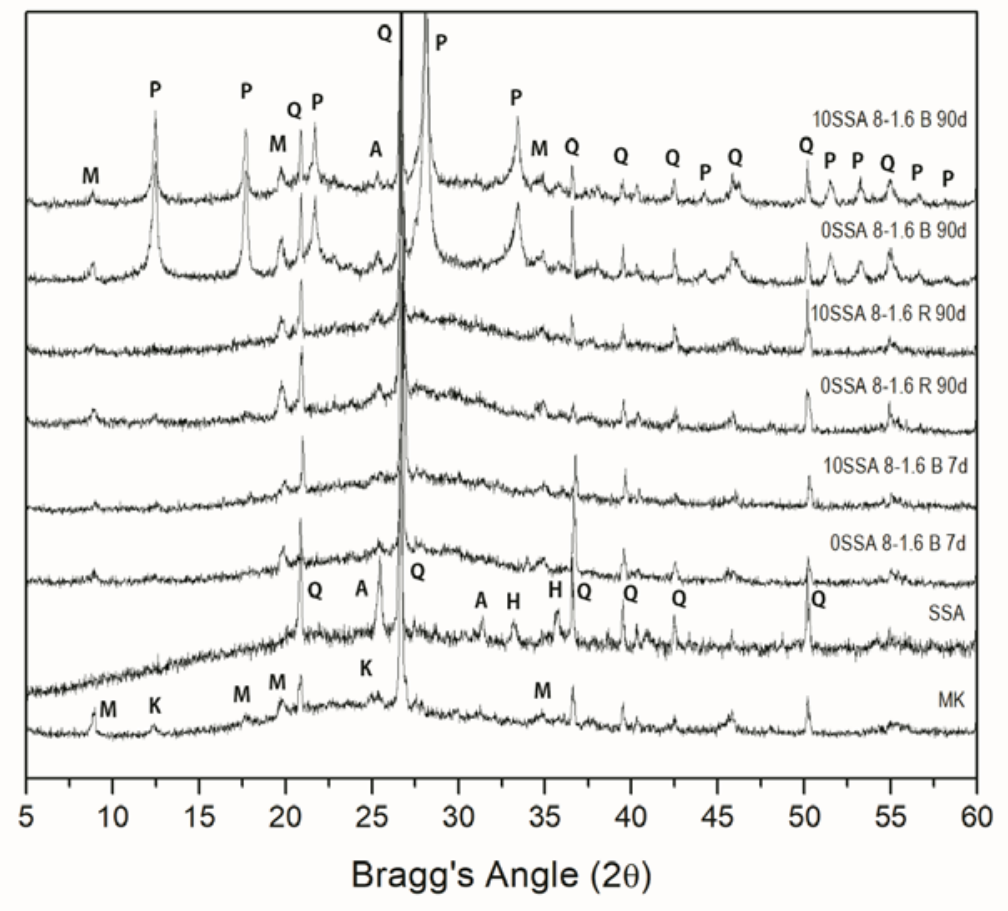




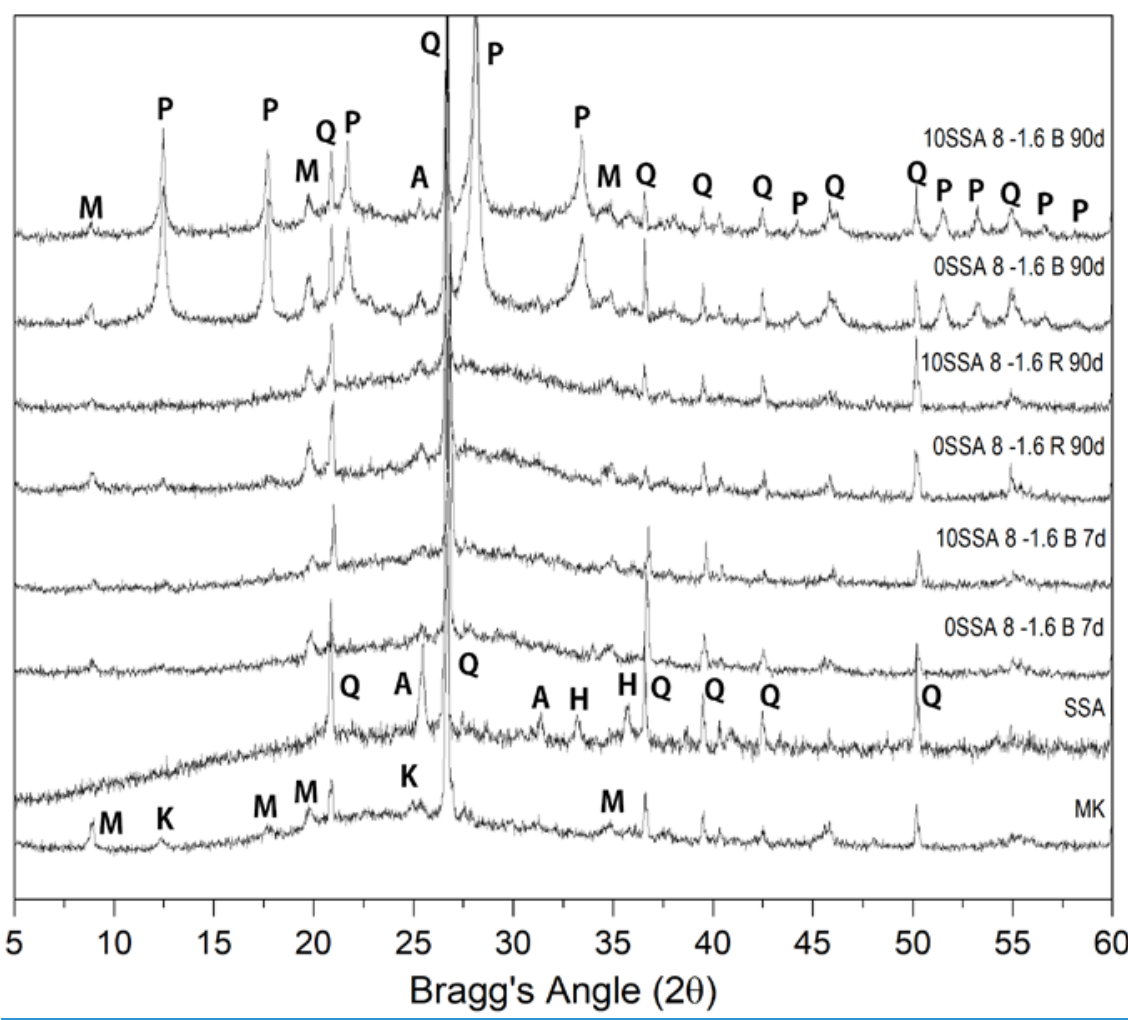

Fig. 4. XRD patterns of SSA/MK geopolymers with a $\mathrm{SiO}_{2} / \mathrm{Na}_{2} \mathrm{O}$ molar ratio of 1.6 (Key: K - Kaolinite; M - Muscovite; P - Na P-type zeolite; Q - Quartz; A - Anhydrite; H Hematite)

\subsection{Fourier-transform infrared spectroscopy TIR analyses}

The infrared spectra of precursors MK and SSA, as well as, the infrared spectra of geopolymeric pastes with the highest $\mathrm{SiO}_{2} / \mathrm{Na}_{2} \mathrm{O}$ molar ratio are given in Fig. $5_{\mathrm{u}}$. In the infrared spectra of the $M K$, the bands at $1032 \mathrm{~cm}^{-1}, 1010 \mathrm{~cm}^{-1}, 534 \mathrm{~cm}^{-1}$ and $424 \mathrm{~cm}^{-1}$ are associated with the tetra-coordinated Si or Al asymmetric stretching vibration of the Si-O-T group ( $T=\mathrm{Si}$ or Al) $[28,41]$. The peaks at $912 \mathrm{~cm}^{-1}$ and $794 \mathrm{~cm}^{-1}$, presented in the spectra of the $\mathrm{MK}$, correspond to the stretching vibration $\mathrm{Al}-\mathrm{OH}$ with coordination $\mathrm{VI}$ [42], which indicated the presence of the kaolinite structure that was confirmed by the XRD analyses. The bending or stretching of T-O-T ( $T=\mathrm{Si}$ or $\mathrm{Al}$ ) bridges of aluminosilicates is assigned to the band at $464 \mathrm{~cm}^{-1}$ [38]. Bands in the regions of frequency $534 \mathrm{~cm}^{-1}$ and $663 \mathrm{~cm}^{-1}$ are linked with Si-O and Al-O vibrations [38,43].

Con formato: Fuente: (Predeterminada) Arial, Inglés (Reino Unido)

Con formato: Fuente: (Predeterminada) Arial

Con formato: Fuente: (Predeterminada) Arial, Inglés (Reino Unido)

Con formato: Fuente: (Predeterminada) Arial

Código de campo cambiado

Con formato: Fuente: (Predeterminada) Arial

Con formato: Fuente: (Predeterminada) Arial 
For SSA spectrum, the asymmetric stretching vibration of the Si-O-T group appeared at $1100,1040,671,665,611$ and $594 \mathrm{~cm}^{-1}$ (Tashima et al., 2017 [243]. The Si-O double band at $796-778$ indicated the presence of quartz [(44]Rodríguez et al., 2010), which was confirmed by the XRD analysis of the SSA.

Accordingly to the literature, the main absorbance band of the geopolymer is in the region attributed to an asymmetric stretching vibration of the Si-O-T group ( $\mathrm{T}=\mathrm{Si}$ or $\mathrm{Al}$ ) in the range of $1300-900 \mathrm{~cm}^{-1}[34,38]$. In Fig. 5 is shown the infrared spectra of geopolymeric pastes with the highest $\mathrm{SiO}_{2} / \mathrm{Na}_{2} \mathrm{O}$ molar ratio (1.6) after 3 and 90 curing days for both room temperature and thermal bath, where can be observed the asymmetric stretching vibration of the Si-O-T group between $991 \mathrm{~cm}^{-1}$ and $977 \mathrm{~cm}^{-1}$.

Furthermore, when these bands are compared to the same band in the infrared spectra of the precursors, MK and SSA, there is a shift of this band to a lower frequency, which is attributed to the formation of an amorphous phase as N-A-S-H gel [445-476]. Such shifts is due to random substitutions of tetrahedral $\mathrm{Si}\left(\mathrm{SiO}_{4}\right)$ by $\mathrm{Al}\left(\mathrm{AlO}_{4}\right)$ in the tridimensional geopolymer structure, which leads to a local change of the Si-O bond environment $[48]$ (Erdogan, 2015).

Comparing the effect of SSA and the curing condition on the infrared spectra of geopolymeric samples, no clear distinction was observed. For all cases, the bands observed in the region of $700-400 \mathrm{~cm}^{-1}$ are attributed to the unreacted phases of precursors (MK and/or SSA).

In Fig. 6 are depicted the infrared spectra of geopolymeric pastes with different $\underline{\mathrm{SiO}_{2}} / \mathrm{Na}_{2} \mathrm{O}$ molar ratio after 90 curing days at both room temperature and thermal bath condition. For all samples, the asymmetric stretching vibration of Si-O-T group are centered between 991 and $974 \mathrm{~cm}^{-1}$. Comparing these values to the bands observed for precursors (1032-1014 $\mathrm{cm}^{-1}$ ), a displacement for lower values are observed indicating the formation of N-A-S-H gel [454-476].

The infrared spectra of the geopolymeric samples with the highest $\mathrm{SiO}_{2} / \mathrm{Na}_{2} \mathrm{O}$ molar ratio and the precursors, MK and SSA, are given in Fig. 5. In the spectra of the MK sample, the bands at $1032 \mathrm{~cm}^{-1}, 424 \mathrm{~cm}^{-1}$-and $534 \mathrm{~cm}^{-1}$-are associated with the tetra-coordinated Si- or Al asymmetric stretching vibration of the Si-O-T group (T-Si-or Al) $[28,41]$. The same asymmetric stretching vibration of the Si-O-T group appeared in the spectra of the SSA $\left(1014 \mathrm{~cm}^{-1}, 516 \mathrm{~cm}^{-1}\right.$ and $\left.424 \mathrm{~cm}^{-1}\right)$. The peaks at $912 \mathrm{~cm}^{-1}$ and $794 \mathrm{~cm}^{-1}$, presented in the spectra of the MK, correspond to the stretching vibration Al-OH with coordination $V 1[42]$, which. These peaks indicated the presence of the kaolinite structure in the mineralogical composition of the metakaolin, which is confirmed by the XRD analyses
Código de campo cambiado

Con formato: Fuente: (Predeterminada) Arial, Sin Resaltar

\section{Código de campo cambiado}

Con formato: Fuente: (Predeterminada) Arial

Con formato: Sin Resaltar

Con formato: Fuente: (Predeterminada) Arial

Con formato: Fuente: (Predeterminada) Arial

Con formato: Fuente: (Predeterminada) Arial Comentado [DI1]: S.T. Erdogan, Properties of Ground Perlite Geopolymer Mortars, J. Mater. Civ. Eng. 27 (2015) 04014210. doi:10.1061/(ASCE)MT.1943-5533.0001172

Con formato: Fuente: (Predeterminada) Arial

Con formato: Superíndice

Con formato: Superíndice

Con formato: Superíndice 
(Kenne Diffo et al., 2015). The bending or stretching of T-O-T (T-Si or Al) bridges of 472 aluminosilicates is assigned to the band at $464 \mathrm{~cm}^{-1}$ [38]. Bands in the regions of 473 frequency $534 \mathrm{~cm}^{-1}$-and $663 \mathrm{~cm}^{-1}$-are linked with Si-O and Al-O vibrations [38,43]. For all 474 geopolymer samples shown in Fig. 5 , the main absorbance band is in the region attributed to an asymmetric stretching vibration of the Si-O-T group ( $T$ - Si-or Al) which is in the range of $1300-900 \mathrm{~cm}^{-1}$ [34]. However, when these bands are compared to the same band of the precursors, there is a shift to-a lower frequency, which is attributed to the formation of an amorphous phase as N-A-S-H gel [44-46]. The geopolymer with SSA displayed the same behaviour compared to the sample with only MK. The peaks in the region of $400-700 \mathrm{~cm}^{-1}$ remained for all geopolymeric samples. The comparison between samples prepared with the highest $\mathrm{SiO}_{2} / \mathrm{Na}_{2} \mathrm{O}$ molar ratio and the lowest $\mathrm{SiO}_{2} / \mathrm{Na}_{2} \mathrm{O}$ 482 molar ratio is shown in Fig. 6 . For both $\mathrm{SiO}_{2} \mathrm{ANa}_{2} \mathrm{O}$ ratios there was a similar significant displacement of the main band centered above $1000 \mathrm{~cm}^{-1}$ from the precursors to a lower frequency ( $980 \mathrm{~cm}^{-1}$-region) for the geopolymeric samples. Additionally, there are no important differences in the FTIR spectra of the samples with 10 wt.\% of SSA (10SSA) 486 and control pastes (OSSA) 


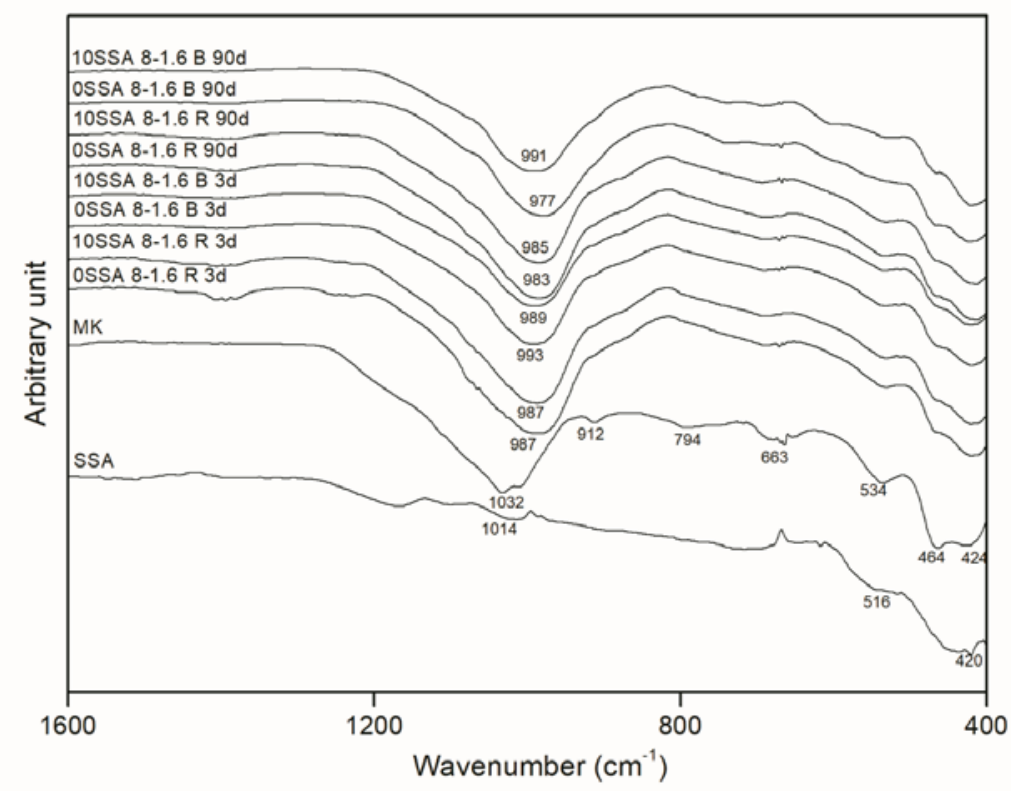

487

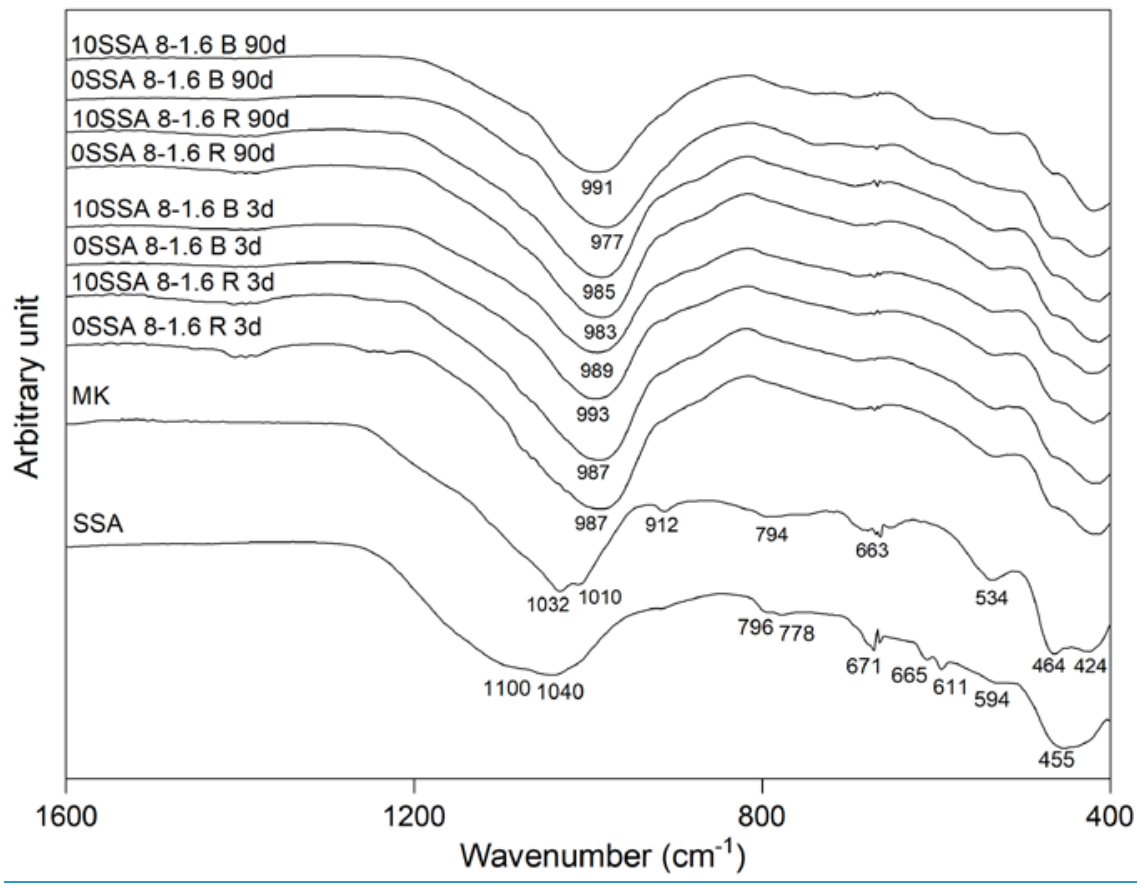


90 days. 


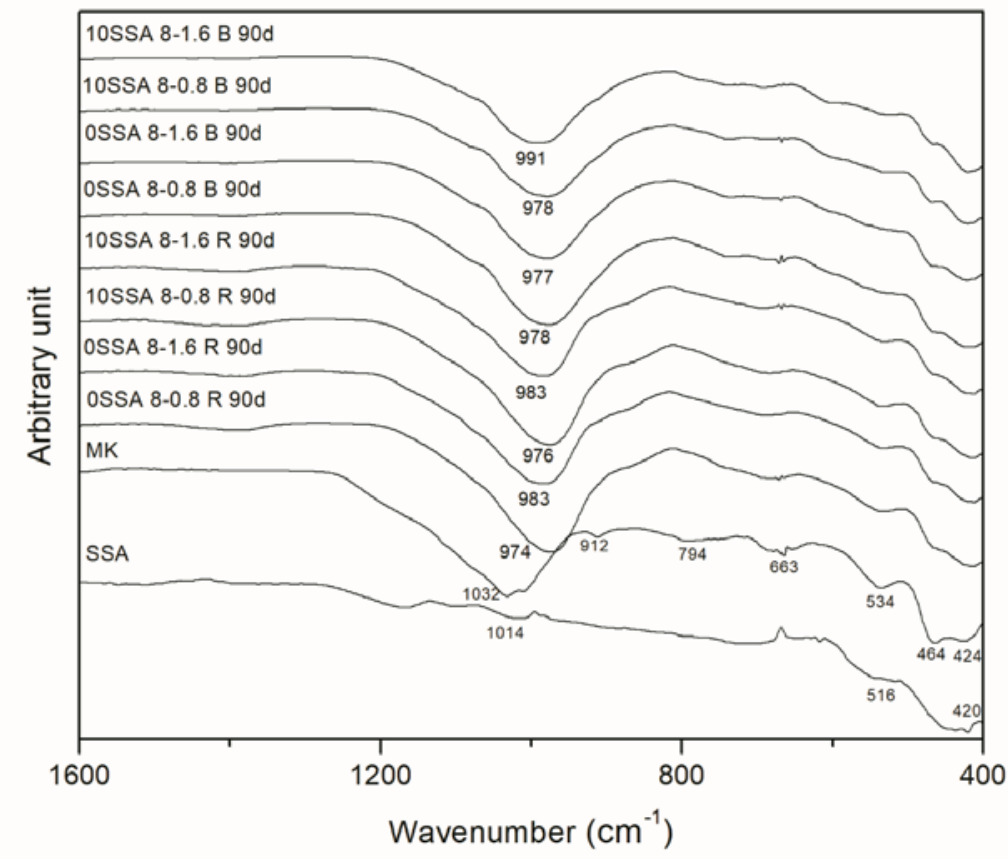




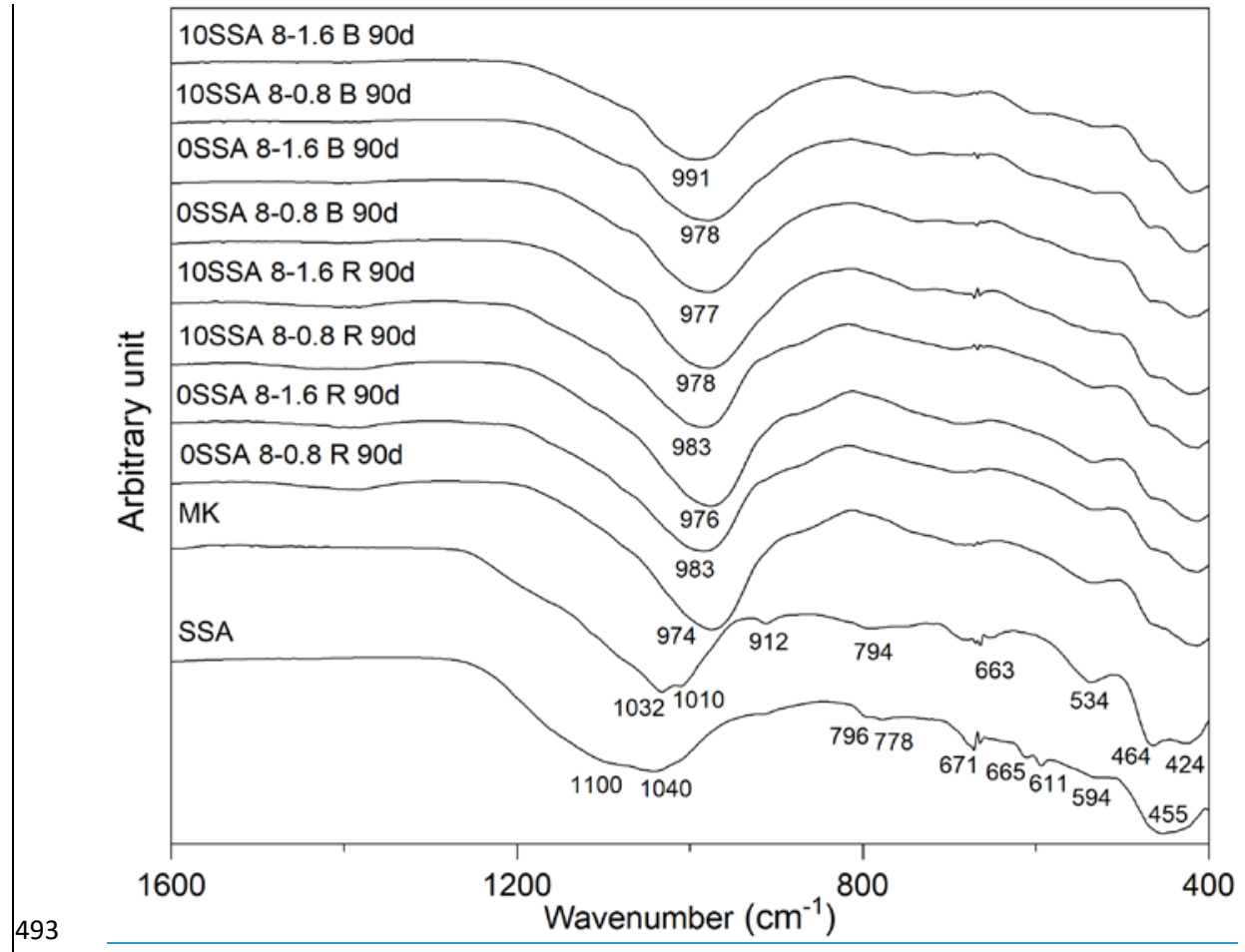

Fig. 6. FTIR comparison between samples with different $\mathrm{SiO}_{2} / \mathrm{Na}_{2} \mathrm{O}$ molar ratios (0.8 and 1,6 ) cured during 90 days at room temperature $(R)$ or in thermal bath $(B)$ condition with 10 wt. $\%$ of SSA (10SSA) and 0 wt.\% of SSA (0SSA).

\subsection{Thermogravimetric $G$ analyses}

TG analyses were carried out on the samples with the highest (1.6) $\mathrm{SiO}_{2} / \mathrm{Na}_{2} \mathrm{O}$ molar ratio cured for 3 and 90 days at room temperature and in a thermal bath, and they are shown as DTG curves in Fig. 7. The TG analyses were exclusively carried out on the samples with the highest $\mathrm{SiO}_{2} / \mathrm{Na}_{2} \mathrm{O}$ molar ratio to assess the influence of the SSA in the mortars that presented superior performance regarding the compressive strength. As can be seen in Fig. 7, two mass losses were remarkable in the geopolymeric samples $\left(L_{1}\right.$ and $\left.L_{2}\right)$.

The $L_{1}$, related to the decomposition in the range $50-200^{\circ} \mathrm{C}$, is attributed to the mass loss of the dehydration of $\mathrm{N}$-A-S-H gels $[26,43,48,49]$ from the activation of the precursors

\begin{tabular}{|l|}
\hline Código de campo cambiado \\
\hline Con formato: Fuente: (Predeterminada) Arial \\
\hline Con formato: Fuente: (Predeterminada) Arial \\
\hline Código de campo cambiado \\
\hline Con formato: Fuente: (Predeterminada) Arial \\
\hline Con formato: Fuente: (Predeterminada) Arial \\
\hline Con formato: Fuente: (Predeterminada) Arial \\
\hline Código de campo cambiado \\
\hline
\end{tabular}


hydroxyl groups) and, on the other hand, the mass loss of the decomposition and

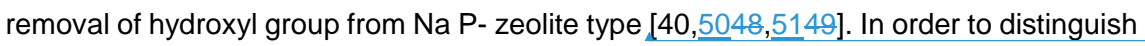
these two events, a mass loss associated only to the zeolite decomposition, which means the mass loss of the peak, was calculated (See Fig. 7, $L_{z}$ ).

In Table $3_{1}$ the amount of the mass loss related to each range of temperature $\left(L_{1}, L_{2}\right)$, the mass loss associated with the zeolite decomposition $\left(L_{z}\right)$ and the total mass loss $\left(L_{T}\right)$ of the geopolymeric samples are shown.

For pastes cured for 3 days, the sample 10SSA cured at both temperatures, $25^{\circ} \mathrm{C}$ and $65{ }^{\circ} \mathrm{C}$, presented greater mass loss (8.6\% and $8.4 \%$, respectively) associated with the first dehydration of N-A-S-H gels $\left(L_{1}\right)$ when compared to the sample 0SSA $(8.2 \%$ and $8.3 \%$, respectively).

For samples cured for 90 days at $65^{\circ} \mathrm{C}$, a peak on the $\mathrm{L}_{2}$ zone of DTG curves could be observed (Fig. 7). This peak is associated with the decomposition of Na P- zeolite type $[40,5048]$. The area of the peak was calculated $\left(L_{z}\right)$. Such behaviour was expected due to the crystallization process $s_{1}$ which usually takes place for long-term curing periods at high curing temperature_[39]. The zeolite formation was also observed on the XRD analyses presented in Fig. 4. Comparing the mass loss associated with the decomposition of zeolites $\left(\mathrm{L}_{z}\right)$ of the sample 10SSA to the control sample, the retarding effect of SSA on the crystallization of MK based-geopolymers for samples cured at 65 ${ }^{\circ} \mathrm{C}(3.7 \%$ for 0SSA and $3.2 \%$ for $10 \mathrm{SSA})$ can be observed. This phenomenon can also be observed on the compressive strength tests.

Table 3. Mass loss from TG analyses of the geopolymers prepared with the highest $\mathrm{SiO}_{2} / \mathrm{Na}_{2} \mathrm{O}$ ratio (1.60). $\mathrm{L}_{T}, \mathrm{~L}_{1}, \mathrm{~L}_{2}$ and $\mathrm{L}_{z}$ are total mass loss, mass loss in the range 35$200{ }^{\circ} \mathrm{C}$, in the range_200-400 ${ }^{\circ} \mathrm{C}$ and mass loss associated to zeolite decomposition, respectively.

\begin{tabular}{cccccccc}
\hline & \multicolumn{6}{c}{ Mass loss (\%) } \\
\cline { 2 - 8 } Geopolymer Samples & \multicolumn{3}{c}{ 3 days of curing } & \multicolumn{5}{c}{90 days of curing } \\
\cline { 2 - 8 } & $\mathrm{L}_{1}$ & $\mathrm{~L}_{2}$ & $\mathrm{~L}_{\mathrm{T}}$ & $\mathrm{L}_{1}$ & $\mathrm{~L}_{2}$ & $\mathrm{~L}_{2}$ & $\mathrm{~L}_{\mathrm{T}}$ \\
\hline 0SSA 8-1.6 R & 8.2 & 4.1 & 13.7 & 8.9 & 4.5 & - & 14.7 \\
\hline 10SSA 8-1.6 R & 8.6 & 4.2 & 14.3 & 8.5 & 4.7 & - & 14.5 \\
\hline 0SSA 8-1.6 B & 8.3 & 4.5 & 14.2 & 4.3 & 7.6 & 3.7 & 13.7 \\
\hline 10SSA 8-1.6 B & 8.4 & 4.4 & 14.3 & 4.5 & 7.2 & 3.2 & 13.5 \\
\hline
\end{tabular}

Con formato: Fuente: (Predeterminada) Arial

Con formato: Fuente: (Predeterminada) Arial

Con formato: Fuente: (Predeterminada) Arial

Con formato: Fuente: (Predeterminada) Arial

Código de campo cambiado

Código de campo cambiado

Con formato: Fuente: (Predeterminada) Arial 

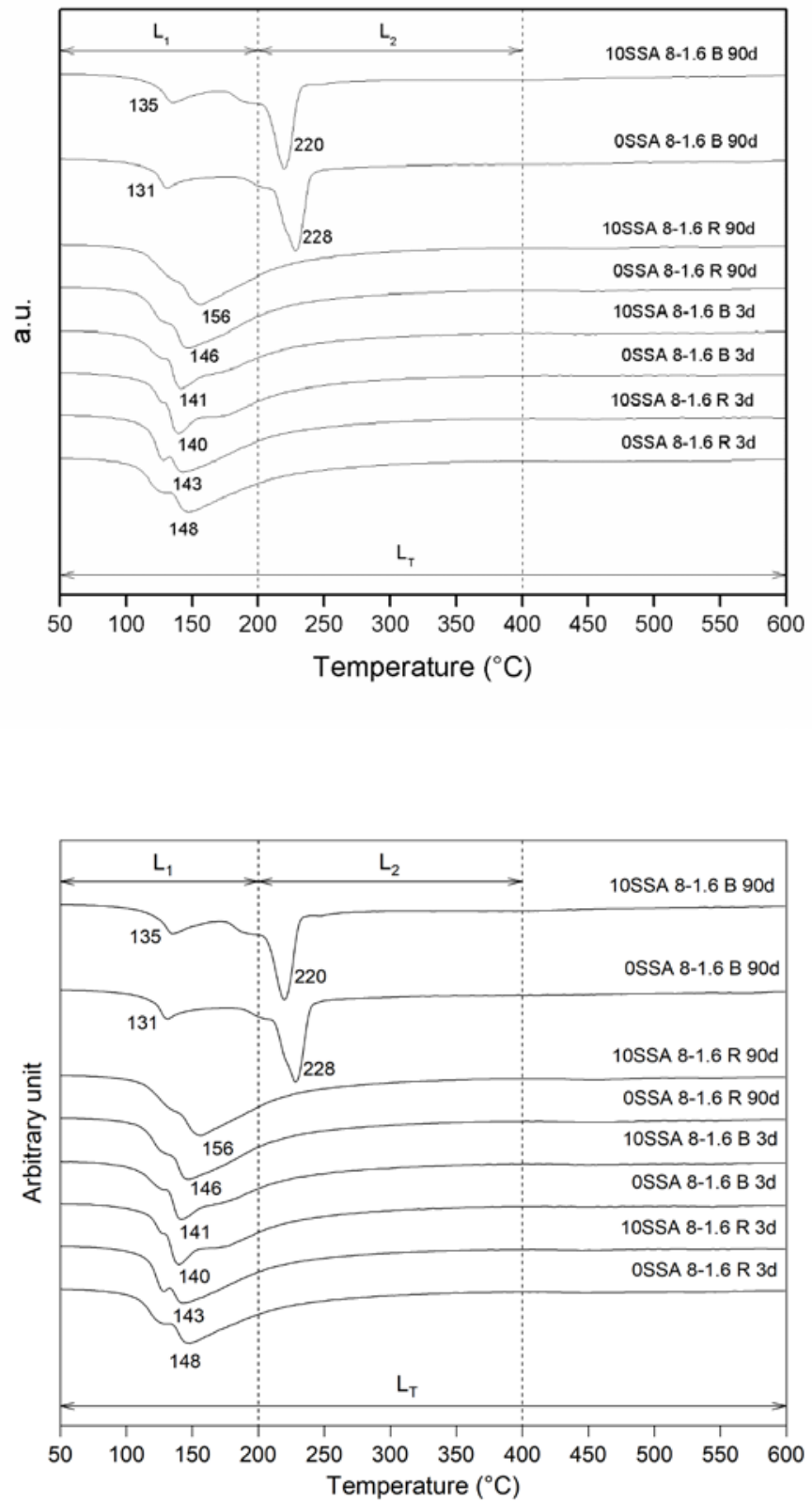
Fig. 7. DTG curves of the geopolymer samples with the highest $\mathrm{SiO}_{2} / \mathrm{Na}_{2} \mathrm{O}$ molar ratio (1.6) with $3(3 d)$ and $90(90 d)$ days of curing at $25^{\circ} \mathrm{C}(\mathrm{R})$ or $65^{\circ} \mathrm{C}(\mathrm{B})-$.

\subsection{Scanning electron microscopyEM analyses}

The microstructures of the geopolymeric pastes were studied by scanning electron microscopy analyses, which were carried out on the samples with the highest (1.6) $\mathrm{SiO}_{2} / \mathrm{Na}_{2} \mathrm{O}$ molar ratios due to the aim to assess the influence of the SSA on microstructure in the mortars that presented superior performance in relation to the compressive strength. In the Fig. 8 the microstructures of the geopolymers with 90 days of curing at $65^{\circ} \mathrm{C}$ are shown. Both microstructures of the OSSA paste (Fig. 8a) and the 10SSA paste (Fig. 8c) presented a significant porosity, that could be due to the crystallization of the geopolymeric gels and, subsequently, to the formation of $\mathrm{Na} \mathrm{P}$-types zeolites 39,52$]$. Na P-types zeolites are identifiable by "ball-wool" (BW) or "pinecone-

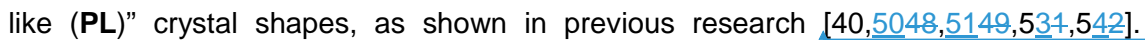
However, Na P-type zeolite with pinecone-like crystal shapes was only identified in the sample 10SSA. In both samples, 0SSA and 10SSA, there were regions represented by the letter A (Fig. 8b) and B (Fig. 8d) that indicated how the crystallization process occurs. It can be seen that the massive geopolymeric gels transintionformation into crystalline phases. Fig. 9a-b and Fig. 9c-d show the microstructure of the samples of OSSA and 10SSA cured for 90 days at $25^{\circ} \mathrm{C}$. Both geopolymeric samples, OSSA and 10SSA, presented massive geopolymeric gels $[43,55]$ and no ordered structure was detected after the first 90 days of curing.
Con formato: Fuente: (Predeterminada) Arial Con formato: Fuente: (Predeterminada) Arial Con formato: Inglés (Estados Unidos)

Código de campo cambiado

Código de campo cambiado

Con formato: Fuente: (Predeterminada) Arial

Con formato: Fuente: (Predeterminada) Arial

Código de campo cambiado

Con formato: Fuente: (Predeterminada) Arial

Con formato: Fuente: (Predeterminada) Arial

Código de campo cambiado

Con formato: Fuente: (Predeterminada) Arial

Código de campo cambiado

Con formato: Fuente: (Predeterminada) Arial

Con formato: Fuente: (Predeterminada) Arial

Código de campo cambiado

Con formato: Fuente: (Predeterminada) Arial

Con formato: Fuente: (Predeterminada) Arial

Código de campo cambiado

Con formato: Fuente: (Predeterminada) Arial

Con formato: Fuente: (Predeterminada) Arial

Código de campo cambiado

Con formato: Fuente: (Predeterminada) Arial

Con formato: Fuente: (Predeterminada) Arial

Código de campo cambiado

Con formato: Fuente: (Predeterminada) Arial

Con formato: Inglés (Reino Unido) 


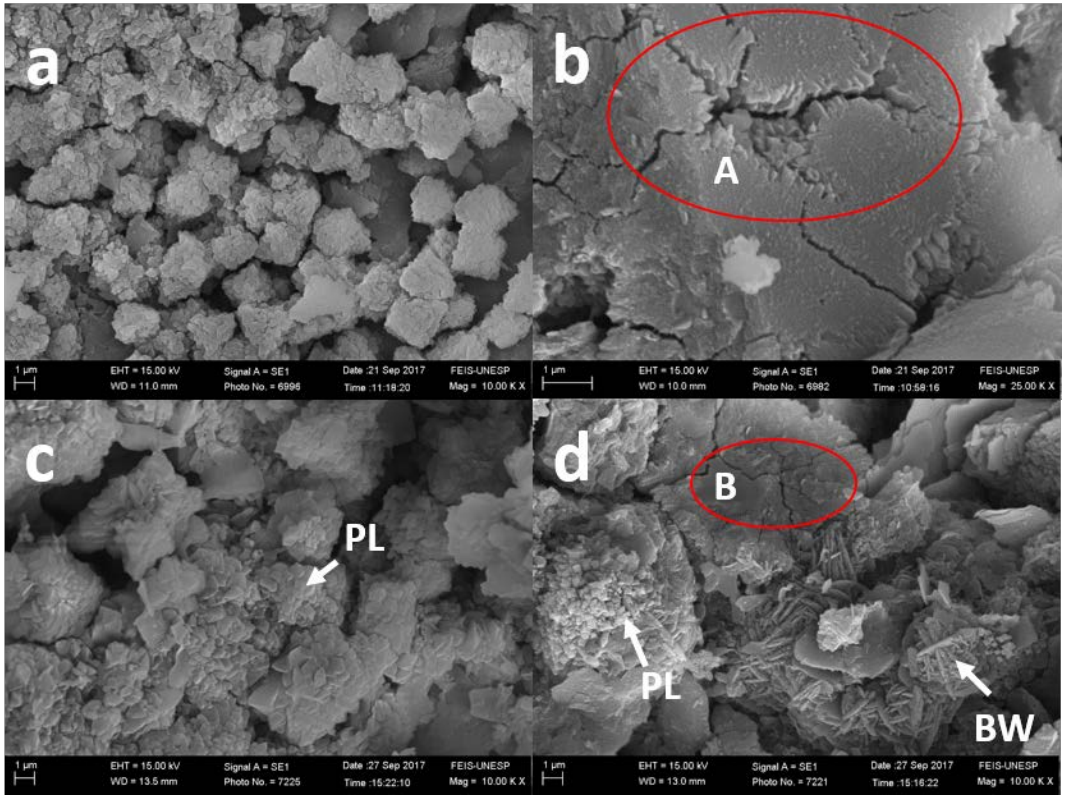

Fig. 8. SEM micrographs of geopolymeric pastes cured at $65^{\circ} \mathrm{C}$ for 90 days with fractured surface: a) and b) 0SSA 8-1.6 B and c) and d) 10SSA 8-1.6 B (Key: PL pinecone-like shape of the zeolite Na P; BW - ball-wool shape of the zeolite Na P; A and B: Transforming process of the geopolymeric gels into crystals). 


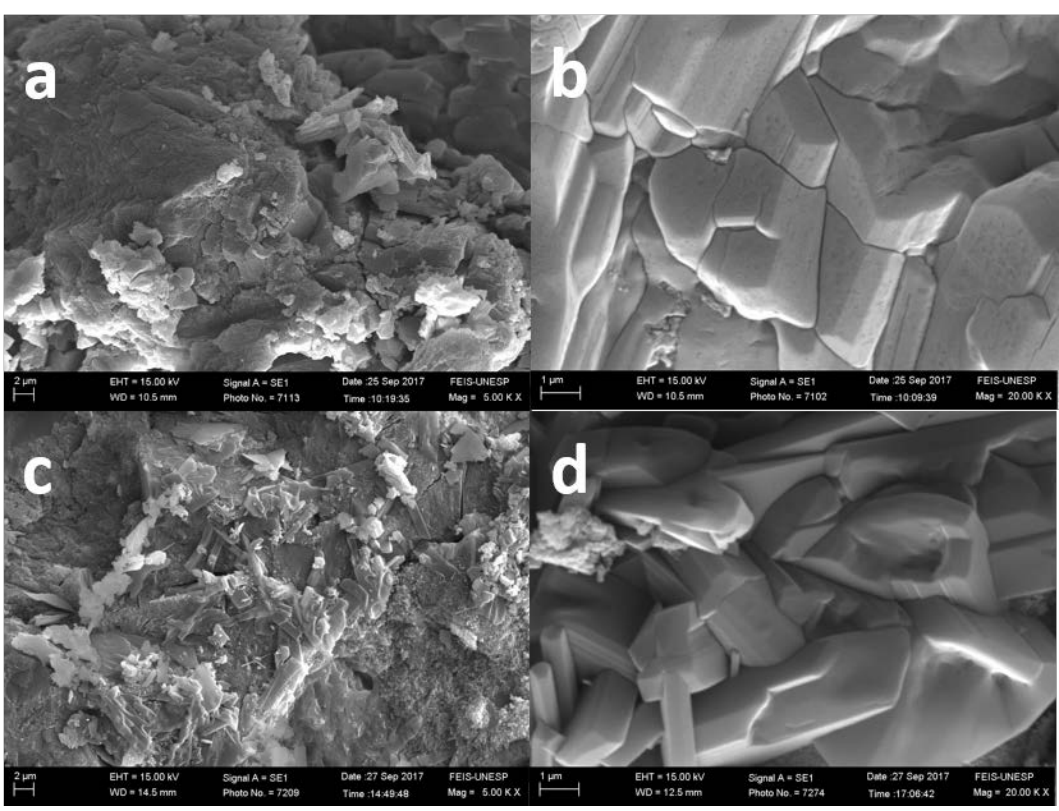

Fig. 9. SEM micrographs of geopolymeric pastes cured at $25^{\circ} \mathrm{C}$ for 90 days with fractured surface: a) and b) 0SSA 8-1.6 R and c) and d) 10SSA 8-1.6 R.

\section{Conclusion}

This paper studied the effect of the SSA on the mechanical and microstructural properties as well as the influence of the $\mathrm{SiO}_{2} / \mathrm{Na}_{2} \mathrm{O}$ molar ratio on the $\mathrm{MK}$ basedgeopolymers resulting from long-curing time at room temperature and in a thermal bath at $65^{\circ} \mathrm{C}$. From the findings that had been presented earlier, the following conclusions were drawn:

580 - Samples with $\mathrm{SiO}_{2} / \mathrm{Na}_{2} \mathrm{O}$ molar ratio 1.6 yielded about $50 \mathrm{MPa}$ after 14 curing days at 581 room temperature for both 0SSA and 10SSA.

- Geopolymeric binders based on MK presented a loss of compressive strength for longcuring time when cured at $65^{\circ} \mathrm{C}$ due the zeolitic phases formation.

In relation to the samples cured at room temperature $\left(25^{\circ} \mathrm{C}\right)$, the highest $\mathrm{SiO}_{2} / \mathrm{Na}_{2} \mathrm{O}$ molar ratio (1.6) provided superior compressive strength in both samples of OSSA (only AK) and 10SSA (10 wt.\% of SSA and 90 wt. \% of MK) compared to the samples with the lowest $\mathrm{SiO}_{2} / \mathrm{Na}_{2} \mathrm{O}$ molar ratio (0.8). The samples with the lowest $\mathrm{SiO}_{2} / \mathrm{Na}_{2} \mathrm{O}$ molar ratio reached compressive strength of 31.2 (OSSA) and $26.4 \mathrm{MPa}$ (10SSA) at 180 days of euring, while for the highest $\mathrm{SiO}_{2} \mathrm{Ala}_{2} \mathrm{O}$ molar ratio the 10SSA samples reached similar compressive strength compared to the OSSA, near 50, after 14 days of treatment.

Con formato: Inglés (Reino Unido)

Con formato: Inglés (Reino Unido) 
- The addition of SSA causes a delaying effect on the hardening process of geopolymeric binders at 1 curing day.

- SSA provided a retarding effect on the crystallization of geopolymeric gels into zeolite phases (Fau-type and Na P-type zeolites), indicating higher stability for geopolymeric gel.

-Both samples' 0SSA and 10SSA with both $\mathrm{SiO}_{2} \mathrm{Na}_{2} \mathrm{O}$ molar ratios presented the metastability behavior when cured at high temperature $\left(65^{\circ} \mathrm{C}\right)$. However, the SSA provided a retarding effect on the transformation of the geopolymeric gels into zeolite phases, primarily in the sample with the highest $\mathrm{SiO}_{2} \mathrm{Naa}_{2} \mathrm{O}$ molar ratio. This means that SSA provides higher stability for geopolymeric samples. The sample containing SSA (10SSA) presented a loss of compressive strength of $44 \%$, while the samples with only MK (OSSA) presented a loss of compressive strength of $51 \%$. In the thermogravimetric analyses, the loss of mass due to the presence of zeolite phases in the geopolymer was lower in the 10SSA sample (3.2\%) than in the 0SSA sample (3.7\%) indicating a retarding effect of SSA in the formation of zeolitic phase.

- The loss of compressive strength of the OSSA and 10SSA samples cured at $65^{\circ} \mathrm{C}$ is due to the formation of zeolite phases. In the samples with the lowest $\mathrm{SiO}_{2} \mathrm{Ala}_{2} \mathrm{O}$ molar ratio, we identified the presence of Fau-type and $\mathrm{Na}$ P-type zeolites. However, in the samples with the highest $\mathrm{SiO}_{z} / \mathrm{Na}_{2} \mathrm{O}$ molar ratio, we identified only an $\mathrm{Na}$ P-type zeolite formation.

-The chemical composition of the SSA caused a delaying effect in the geopolymerization reaction, mainly in the samples with the highest $\mathrm{SiO}_{2} / \mathrm{Na}_{2} \mathrm{O}$ molar ratios, for both temperature of curing. The samples with SSA (10SSA) at 1 day of curing presented a compressive strength 24\% lower than the sample with only MKK (OSSA) regarding mortars with the lowest $\mathrm{SiO}_{2} / \mathrm{Na}_{2} \mathrm{O}$ molar ratio. In relation of the mortar with the highest $\mathrm{SiO}_{2} / \mathrm{Na}_{2} \mathrm{O}$ molar ratio, the compressive strengths of the sample $10 \mathrm{SSA}$ were $43 \%$ and $59 \%$ lower than the values found for the sample 0SSA when cured at $25^{\circ} \mathrm{C}$ and $65^{\circ} \mathrm{C}$, respectively.

\section{Acknowledgments}

This research has been supported by funding agency Coordenação de Aperfeiçoamento de Pessoal de Nível Superior (CAPES) and Conselho Nacional de Desenvolvimento Científico e Tecnológico (CNPq) (processo nº 309015/2015-4).

\section{References}

[1] G. Habert, J.B. D'Espinose De Lacaillerie, N. Roussel, An environmental evaluation of geopolymer based concrete production: Reviewing current research trends, J. Clean. Prod. 19 (2011) 1229-1238. doi:10.1016/j.jclepro.2011.03.012.

[2] M.M. Hossain, M.R. Karim, M.K. Hossain, M.N. Islam, M.F.M. Zain, Durability of mortar and concrete containing alkali-activated binder with pozzolans: A review, Constr. Build. Mater. 93 (2015) 95-109. doi:10.1016/j.conbuildmat.2015.05.094.

[3] B. Singh, G. Ishwarya, M. Gupta, S.K. Bhattacharyya, Geopolymer concrete: A review of some recent developments, Constr. Build. Mater. 85 (2015) 78-90. 
doi:10.1016/j.conbuildmat.2015.03.036.

[4] A. Koleżyński, M. Król, M. Żychowicz, The structure of geopolymers Theoretical studies, J. Mol. Struct. 1163 (2018) 465-471. doi:10.1016/j.molstruc.2018.03.033.

[5] Y.M. Liew, C.Y. Heah, A.B. Mohd Mustafa, H. Kamarudin, Structure and properties of clay-based geopolymer cements: A review, Prog. Mater. Sci. 83 (2016) 595-629. doi:10.1016/j.pmatsci.2016.08.002.

[6] J. Payá, J. Monzó, M. V Borrachero, M.M. Tashima, Reuse of aluminosilicate industrial waste materials in the production of alkali-activated concrete binders, Woodhead Publishing Limited, 2015. doi:http://dx.doi.org/10.1533/9781782422884.4.487.

[7] E. Nimwinya, W. Arjharn, S. Horpibulsuk, T. Phoo-ngernkham, A. Poowancum, A sustainable calcined water treatment sludge and rice husk ash geopolymer, $\mathrm{J}$. Clean. Prod. 119 (2015) 128-134. doi:10.1016/j.jclepro.2016.01.060.

[8] S. Yan, K. Sagoe-Crentsil, Properties of wastepaper sludge in geopolymer mortars for masonry applications., J. Environ. Manage. 112 (2012) 27-32. doi:10.1016/j.jenvman.2012.07.008.

[9] WWAP, Wastewater. The Untapped Ressource, 2017 http://unesdoc.unesco.org/images/0024/002471/247153e.pdf.

[10] P. Drechsel, M. Qadir, D. Wichelns, Wastewater: Economic asset in an urbanizing world, Wastewater Econ. Asset an Urban. World. (2015) 1-282. doi:10.1007/978-94-017-9545-6.

[11] A. Kelessidis, A.S. Stasinakis, Comparative study of the methods used for treatment and final disposal of sewage sludge in European countries, Waste Manag. 32 (2012) 1186-1195. doi:10.1016/j.wasman.2012.01.012.

[12] M. Smol, J. Kulczycka, A. Henclik, K. Gorazda, Z. Wzorek. The possible use of sewage sludge ash (SSA) in the construction industry as a way towards a circular economy, J. Clean. Prod. 95 (2015) 45-54. doi:10.1016/j.jclepro.2015.02.051.

[173] J. Monzó, J. Payá, M. V Borrachero, I. Girbés, Reuse of sewage sludge ashes (SSA) in cement mixtures: the effect of SSA on the workability of cement mortars., Waste Manag. 23 (2003) 373-81. doi:10.1016/S0956-053X(03)00034$\underline{\underline{5}}$

[184] R.O. Yusuf, Z.Z. Noor, N.A. Moh', d F. Moh', D. Din, A.H. Abba, Use of sewage sludge ash (SSA) in the production of cement and concrete - a review, Int. J. Glob. Environ. Issues. 12 (2012) 214. doi:10.1504/IJGENVI.2012.049382.

[195] M.T. Perez Carrion, F. Baeza Brotons, P. Garcés, O. Galao Malo, J. Paya Bernabeu, Potencial use of Sewage Sludge Ash as a Fine Aggregate Replacement in Precast Concrete Blocks, Dyna-Colombia. 80 (2013) 142-150.

[2106] M. Tarrago, M. Garcia-Valles, M.H. Aly, S. Mart??nez, Valorization of sludge from a wastewater treatment plant by glass-ceramic production, Ceram. Int. 43 (2017) 930-937. doi:10.1016/j.ceramint.2016.10.083.

[2117]F. Baeza, J. Payá, O. Galao, J.M. Saval, P. Garcés, Blending of industrial waste from different sources as partial substitution of Portland cement in pastes and 
mortars, Constr. Build. Mater. 66 (2014) 645-653. doi:10.1016/j.conbuildmat.2014.05.089.

[18] C.J.C.J.C.J. Lynn, R.K. Dhir, G.S. Ghataora, R.P. West, Sewage sludge ash characteristics and potential for use in concrete, Constr. Build. Mater. 98 (2015) 767-779. doi:10.1016/j.conbuildmat.2015.08.122.

[1319] M. Cyr, M. Coutand, P. Clastres, Technological and environmental behavior of sewage sludge ash (SSA) in cement-based materials, Cem. Concr. Res. 37 (2007) 1278-1289. doi:10.1016/j.cemconres.2007.04.003.

[1420] P. Garcés, M. Pérez Carrión, E. García-Alcocel, J. Payá, J. Monzó, M. V Borrachero, Mechanical and physical properties of cement blended with sewage sludge ash., Waste Manag. 28 (2008) 2495-502. doi:10.1016/j.wasman.2008.02.019.

[1521] S.-C. Pan, D.-H. Tseng, C.-C. Lee, C. Lee, Influence of the fineness of sewage sludge ash on the mortar properties, Cem. Concr. Res. 33 (2003) 1749-1754. doi:10.1016/S0008-8846(03)00165-0.

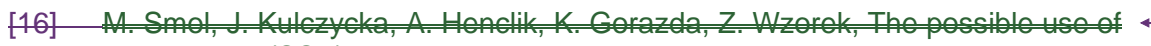
sewage sludge ash (SSA) in the construction industry as a way towards a circular

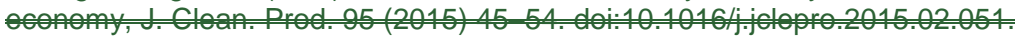

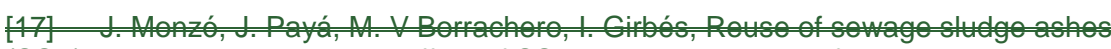
(SSA) in cement mixtures: the effect of SSA on the workability of cement mortars., Waste Manag. 23 (2003) 373-81. doi:10.1016/S0956-053x(03)00034-5.

[18] R.O. Yusuf, Z.Z. Noor, N.A. Moh', dF. Moh', D. Din, A.H. Abba, Use of sewage

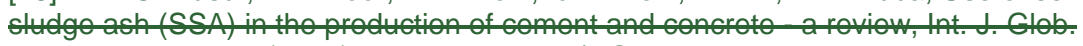
Environ. Issues. 12 (2012) 214. doi:10.1504/1JGENV1.2012.049382.

[19] M.T.Perez Garrion, F. Baeza Brotons, P. Garcés, O. Galao Malo, J.Paya Bernabeu, Potencial use of Sewage Sludge Ash as a Fine Aggregate Replacement in Precast Concrete Blocks, Dyna-Colombia. 80-(2013) 142 150 .

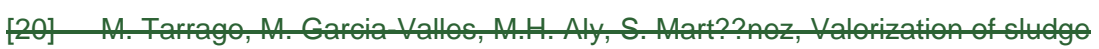
from a wastewater treatment plant by glass-ceramic production, Ceram. Int. $43(2017)$ 930 937. doi:10.1016/j.ceramint.2016.10.083.

[21] F. Baeza, J.Payá, O. Galao, J.M. Saval, P. Garcés, Blending of industrial waste

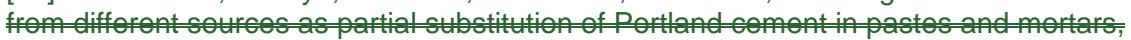
Constr. Build. Mater. 66 (2014) 645 653. doi:10.1016/j.conbuildmat.2014.05.089.

[22] N. Yamaguchi, K. Ikeda, Preparation of geopolymeric materials from sewage sludge slag with special emphasis to the matrix compositions, J. Ceram. Soc. Japan. 118 (2010) 107-112. doi:10.2109/jcersj2.118.107.

[23] D.B. Istuque, L. Reig, J.C.B. Moraes, J.L. Akasaki, M.V. Borrachero, L. Soriano, J. Payá, J.A. Malmonge, M.M. Tashima, Behaviour of metakaolin-based geopolymers incorporating sewage sludge ash (SSA), Mater. Lett. 180 (2016) 192-195. doi:10.1016/j.matlet.2016.05.137.

[2423] M.M. Tashima, L. Reig, M.A. Santini, J.C. B Moraes, J.L. Akasaki, J. Payá, M. V. Borrachero, L. Soriano, Compressive Strength and Microstructure of AlkaliActivated Blast Furnace Slag/Sewage Sludge Ash (GGBS/SSA) Blends Cured at Room Temperature, Waste and Biomass Valorization. 8 (2017) 1441-1451. doi:10.1007/s12649-016-9659-1.

[2524] S. Chakraborty, B.W. Jo, J.H. Jo, Z. Baloch, Effectiveness of sewage sludge ash
Con formato: Inglés (Reino Unido)

Con formato: Inglés (Reino Unido)

Con formato: Inglés (Reino Unido)

Con formato: Inglés (Reino Unido)

Con formato: Sangría: Izquierda: $0 \mathrm{~cm}$, Primera línea: $0 \mathrm{~cm}$

Con formato: Inglés (Reino Unido)

Con formato: Inglés (Reino Unido)

Con formato: Inglés (Reino Unido) 
combined with waste pozzolanic minerals in developing sustainable construction material: An alternative approach for waste management, J. Clean. Prod. 153 (2017) 253-263. doi:10.1016/j.jclepro.2017.03.059.

[25] D.B. Istuque, L. Reig, J.C.B. Moraes, J.L. Akasaki, M.V. Borrachero, L. Soriano, J. Payá, J.A. Malmonge, M.M. Tashima, Behaviour of metakaolin-based geopolymers incorporating sewage sludge ash (SSA), Mater. Lett. 180 (2016) 192-195. doi:10.1016/i.matlet.2016.05.137.

[26] H. Cheng, K.-L. Lin, R. Cui, C.-L. Hwang, Y.-M. Chang, T.-W. Cheng, The effects of $\mathrm{SiO} 2 / \mathrm{Na} 2 \mathrm{O}$ molar ratio on the characteristics of alkali-activated waste catalyst-metakaolin based geopolymers, Constr. Build. Mater. 95 (2015) 710720. doi:10.1016/j.conbuildmat.2015.07.028.

[27] B. Mo, H. Zhu, X. Cui, Y. He, S. Gong, Effect of curing temperature on geopolymerization of metakaolin-based geopolymers, Appl. Clay Sci. 99 (2014) 144-148. doi:10.1016/j.clay.2014.06.024.

[28] F.G.M. Aredes, T.M.B. Campos, J.P.B. Machado, K.K. Sakane, G.P. Thim, D.D. Brunelli, Effect of cure temperature on the formation of metakaolinite-based geopolymer, Ceram. Int. 41 (2015) 7302-7311. doi:10.1016/j.ceramint.2015.02.022.

[29] C. Shi, A.F. Jiménez, A. Palomo, New cements for the 21st century: The pursuit of an alternative to Portland cement, Cem. Concr. Res. 41 (2011) 750-763. doi:10.1016/j.cemconres.2011.03.016.

[30] K. Gao, K.-L. Lin, D. Wang, C.-L. Hwang, H.-S. Shiu, Y.-M. Chang, T.-W. Cheng, Effects $\mathrm{SiO} 2 / \mathrm{Na} 2 \mathrm{O}$ molar ratio on mechanical properties and the microstructure of nano-SiO2 metakaolin-based geopolymers, Constr. Build. Mater. 53 (2014) 503-510. doi:10.1016/j.conbuildmat.2013.12.003.

[31] A. Fernández-Jiménez, N. Cristelo, T. Miranda, Á. Palomo, Sustainable alkali activated materials: Precursor and activator derived from industrial wastes, J. Clean. Prod. 162 (2017) 1200-1209. doi:10.1016/j.jclepro.2017.06.151.

[32] J.G. Jang, H.K. Lee, Effect of fly ash characteristics on delayed high-strength development of geopolymers, Constr. Build. Mater. 102 (2016) 260-269. doi:10.1016/J.CONBUILDMAT.2015.10.172.

[33] H.Y. Zhang, V. Kodur, S.L. Qi, B. Wu, Characterizing the bond strength of geopolymers at ambient and elevated temperatures, Cem. Concr. Compos. 58 (2015) 40-49. doi:10.1016/j.cemconcomp.2015.01.006.

[34] P. Rovnaník, Effect of curing temperature on the development of hard structure of metakaolin-based geopolymer, Constr. Build. Mater. 24 (2010) 1176-1183. doi:10.1016/j.conbuildmat.2009.12.023.

[35] A. Aboulayt, R. Jaafri, H. Samouh, A. Cherki El Idrissi, E. Roziere, R. Moussa, A. Loukili, Stability of a new geopolymer grout: Rheological and mechanical performances of metakaolin-fly ash binary mixtures, Constr. Build. Mater. 181 (2018) 420-436. doi:10.1016/J.CONBUILDMAT.2018.06.025.

[36] A. Autef, E. Joussein, G. Gasgnier, S. Pronier, I. Sobrados, J. Sanz, S. Rossignol, Role of metakaolin dehydroxylation in geopolymer synthesis, Powder Technol. 250 (2013) 33-39. doi:10.1016/j.powtec.2013.09.022.

[37] P. Timakul, W. Rattanaprasit, P. Aungkavattana, Improving compressive 
strength of fly ash-based geopolymer composites by basalt fibers addition, Ceram. Int. 42 (2016) 6288-6295. doi:10.1016/j.ceramint.2016.01.014.

[38] I. Ozer, S. Soyer-Uzun, Relations between the structural characteristics and compressive strength in metakaolin based geopolymers with different molar Si/Al ratios, Ceram. Int. 41 (2015) 10192-10198. doi:10.1016/j.ceramint.2015.04.125.

[39] X. Ma, Z. Zhang, A. Wang, The transition of fly ash-based geopolymer gels into ordered structures and the effect on the compressive strength, Constr. Build. Mater. 104 (2016) 25-33. doi:10.1016/j.conbuildmat.2015.12.049.

[40] P. Pal, J.K. Das, N. Das, S. Bandyopadhyay, Synthesis of NaP zeolite at room temperature and short crystallization time by sonochemical method, Ultrason. Sonochem. 20 (2013) 314-321. doi:10.1016/j.ultsonch.2012.07.012.

[41] P.N. Lemougna, K. Wang, Q. Tang, U.C. Melo, X. Cui, Recent developments on inorganic polymers synthesis and applications, Ceram. Int. 42 (2016) 1514215159. doi:10.1016/j.ceramint.2016.07.027.

[42] B.B. Kenne Diffo, A. Elimbi, M. Cyr, J. Dika Manga, H. Tchakoute Kouamo, Effect of the rate of calcination of kaolin on the properties of metakaolin-based geopolymers, J. Asian Ceram. Soc. 3 (2015) 130-138. doi:10.1016/j.jascer.2014.12.003.

[43] H.K. Tchakouté, C.H. Rüscher, S. Kong, E. Kamseu, C. Leonelli, Geopolymer binders from metakaolin using sodium waterglass from waste glass and rice husk ash as alternative activators: A comparative study, Constr. Build. Mater. 114 (2016) 276-289. doi:10.1016/j.conbuildmat.2016.03.184.

[44] N.H. Rodríquez, S.M. Ramírez, M.T.B. Varela, M. Guillem, J. Puiq, E. Larrotcha, J. Flores, Re-use of drinking water treatment plant (DWTP) sludge:

Characterization and technological behaviour of cement mortars with atomized sludge additions, Cem. Concr. Res. 40 (2010) 778-786. doi:10.1016/i.cemconres.2009.11.012.

[454] A. Vásquez, V. Cárdenas, R.A. Robayo, R.M. de Gutiérrez, Geopolymer based on concrete demolition waste, Adv. Powder Technol. 27 (2015) 1173-1179. doi:10.1016/j.apt.2016.03.029.

[465] Z. Sun, H. Cui, H. An, D. Tao, Y. Xu, J. Zhai, Q. Li, Synthesis and thermal behavior of geopolymer-type material from waste ceramic, Constr. Build. Mater. 49 (2013) 281-287. doi:10.1016/j.conbuildmat.2013.08.063.

[476] M. Zhang, M. Zhao, G. Zhang, T. El-Korchi, M. Tao, A multiscale investigation of reaction kinetics, phase formation, and mechanical properties of metakaolin geopolymers, Cem. Concr. Compos. 78 (2017) 21-32. doi:10.1016/j.cemconcomp.2016.12.010.

[48] Z. Huo, X. Xu, Z. Lü, J. Song, M. He, Z. Li, Q. Wang, L. Yan, Synthesis of zeolite $\mathrm{NaP}$ with controllable morphologies, Microporous Mesoporous Mater. 158 (2012) 137-140. doi:10.1016/J.MICROMESO.2012.03.026.

S.T. Erdogan, Properties of Ground Perlite Geopolymer Mortars, J. Mater. Civ. Eng. 27 (2015) 04014210. doi:10.1061/(ASCE)MT.1943-5533.0001172.

[497] J.C.B. Moraes, M.M. Tashima, J.L. Akasaki, J.L.P. Melges, J. Monzó, M.V. Borrachero, L. Soriano, J. Payá, Effect of sugar cane straw ash (SCSA) as solid precursor and the alkaline activator composition on alkali-activated binders based on blast furnace slag (BFS), Constr. Build. Mater. 144 (2017) 214-224. doi:10.1016/J.CONBUILDMAT.2017.03.166.

Con formato: Fuente: (Predeterminada) Arial

Con formato: Inglés (Reino Unido)

Con formato: Inglés (Reino Unido)

Con formato: Inglés (Reino Unido)

Con formato: Inglés (Reino Unido)

Con formato: Inglés (Reino Unido)

Con formato: Inglés (Reino Unido)

Con formato: Inglés (Reino Unido) 
[5048]Z. Huo, X. Xu, Z. Lü, J. Song, M. He, Z. Li, Q. Wang, L. Yan, Synthesis of zeolite $\mathrm{NaP}$ with controllable morphologies, Microporous Mesoporous Mater. 158 (2012) 137-140. doi:10.1016/J.MICROMESO.2012.03.026.

[5149]Z. Huo, X. Xu, Z. Lv, J. Song, M. He, Z. Li, Q. Wang, L. Yan, Y. Li, Thermal study of NaP zeolite with different morphologies, J. Therm. Anal. Calorim. 111 (2013) 365-369. doi:10.1007/s10973-012-2301-y.

[520] J.P. Gevaudan, K.M. Campbell, T.J. Kane, R.K. Shoemaker, W. V. Srubar, Mineralization dynamics of metakaolin-based alkali-activated cements, Cem. Concr. Res. 94 (2017) 1-12. doi:10.1016/J.CEMCONRES.2017.01.001.

[513] Q. Tang, Y.Y. Ge, K.T. Wang, Y. He, X.M. Cui, Preparation of porous P-type zeolite spheres with suspension solidification method, Mater. Lett. 161 (2015) 558-560. doi:10.1016/j.matlet.2015.09.062.

[542] N.K. Lee, H.R. Khalid, H.K. Lee, Synthesis of mesoporous geopolymers containing zeolite phases by a hydrothermal treatment, Microporous Mesoporous Mater. 229 (2016) 22-30. doi:10.1016/j.micromeso.2016.04.016.

[553] Q. Wan, F. Rao, S. Song, R.E. García, R.M. Estrella, C.L. Patiño, Y. Zhang, Geopolymerization reaction, microstructure and simulation of metakaolin-based geopolymers at extended Si/Al ratios, Cem. Concr. Compos. 79 (2017) 45-52. doi:10.1016/j.cemconcomp.2017.01.014.
Con formato: Inglés (Reino Unido)

Con formato: Inglés (Reino Unido)

Con formato: Inglés (Reino Unido)

Con formato: Inglés (Reino Unido)

Con formato: Inglés (Reino Unido)

Con formato: Inglés (Reino Unido)

Con formato: Inglés (Reino Unido)

Con formato: Inglés (Estados Unidos)

Con formato: Sangría: Izquierda: $0 \mathrm{~cm}$, Sangría francesa: $1,13 \mathrm{~cm}$, No ajustar espacio entre texto latino y asiático, No ajustar espacio entre texto asiático y números

Con formato: Inglés (Estados Unidos)

Con formato: Inglés (Estados Unidos) 